
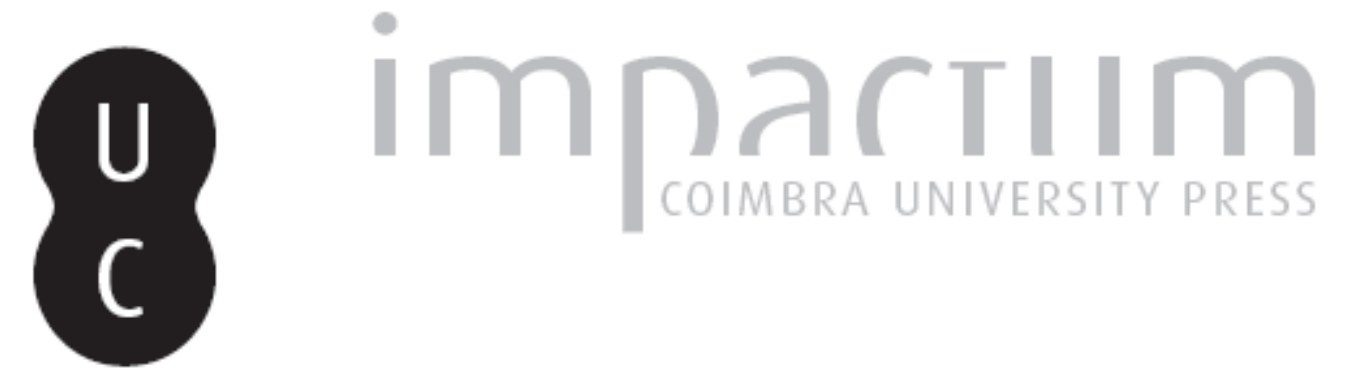

\title{
Filosofia e mistérios: leitura do Proêmio de Parmênides
}

Autor(es): Bernabé, Alberto

Publicado por: Annablume Clássica

URL persistente: URI:http://hdl.handle.net/10316.2/24320

\section{Accessed : $\quad$ 26-Apr-2023 15:00:56}

A navegação consulta e descarregamento dos títulos inseridos nas Bibliotecas Digitais UC Digitalis, UC Pombalina e UC Impactum, pressupõem a aceitação plena e sem reservas dos Termos e Condições de Uso destas Bibliotecas Digitais, disponíveis em https://digitalis.uc.pt/pt-pt/termos.

Conforme exposto nos referidos Termos e Condições de Uso, o descarregamento de títulos de acesso restrito requer uma licença válida de autorização devendo o utilizador aceder ao(s) documento(s) a partir de um endereço de IP da instituição detentora da supramencionada licença.

Ao utilizador é apenas permitido o descarregamento para uso pessoal, pelo que o emprego do(s) título(s) descarregado(s) para outro fim, designadamente comercial, carece de autorização do respetivo autor ou editor da obra.

Na medida em que todas as obras da UC Digitalis se encontram protegidas pelo Código do Direito de Autor e Direitos Conexos e demais legislação aplicável, toda a cópia, parcial ou total, deste documento, nos casos em que é legalmente admitida, deverá conter ou fazer-se acompanhar por este aviso. 

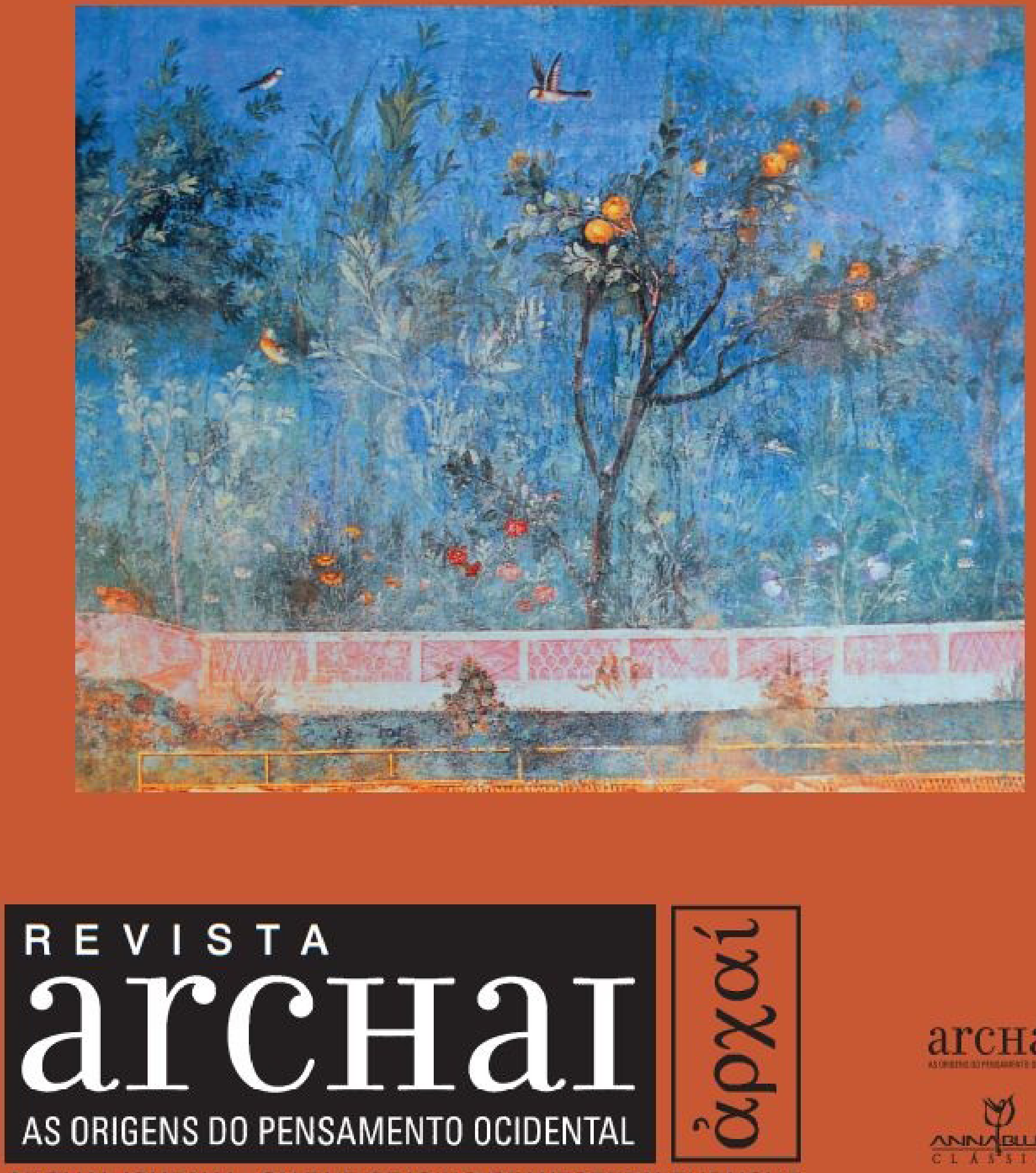

arcнаI

ARCHAI JOURNAL: ON THE ORIGINS OF WESTERN THOUGHT

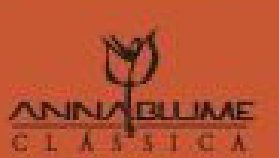




\section{FILOSOFIA E MISTÉRIOS: LEITURA DO PROÊMIO DE PARMÊNIDES*}

BERNABÉ, A. (2013). Filosofia e mistérios: leitura do proêmio de Parmênides. Archai, n. 10, jan-jul, p. 37-58.

RESUMO: Tem-se analisado, recorrentemente, a influência de Homero e de Hesíodo no proêmio do poema de Parmênides. As possíveis influências da poesia órfica tem sido apenas consideradas. Todavia, diversas descobertas de textos órficos aconselham voltar a analisar os vestígios da tradição mistérica, em geral, e órfica, em particular, no poema do filósofo de Eléia, sem minimizar, com isso, as outras influências já postas em relevo. 0 autor assinalou, em um trabalho anterior, algumas conexões entre Parmênides e os textos órficos; neste artigo, a análise se centra nos pontos de contato com ideias e imagens literárias dos Mistérios que se encontram no proêmio. Não se trata de determinar as crenças do filósofo, senão de situar, no âmbito da tradição, os conteúdos doutrinais e/ou poéticos expressados nesta parte fundamental do seu poema, para fazer ver o que têm de poderosamente originais e, em consequência, tratar de determinar o significado do proêmio no conjunto da obra.

PALAVRAS-CHAVE: Filosofia grega, Parmênides, Orfismo, Mistérios, Épica arcaica.

ABSTRACT: Homeric and Hesiodic influences on Parmenides's proem have been often pointed out, whereas possible traces of the Orphic poetry have been frequently dismised. Nevertheless some new Orphic texts call for a new analysis of the traces of mystery traditions in general and Orphic in particular on the poem of the Eleatic philosopher, without minimizing other influences before shown. In a previus work the author pointed out some connections between Parmenides' poem and Orphic texts; in this
* Este trabalho é parte de uma investigação financiada pelo Ministério da Economia e Inovação (FFI2010.17047). Desejo agradecer a Miguel Herrero, Ana Jiménez San Cristóbal, Madayo Kahle, Raquel Martín, Alexander Mourelatos e Marco Antonio Santamaría por terem lido

o manuscrito e terem me fornecido interessantes contribuições. Ele foi publicado originalmente em: Uma mirada actual a la filosofía griega: Ponencias del II Congreso Internacional de Filosofía Griega de la Sociedad Ibérica de Filosofía Griega. Ediciones de la SIFG: Madrid-Mallorca, 2012, pp. 3-40; com o título: Filosofía y Misterios.

Lectura del Proemio de Parménides. Todas as citações originais em grego foram transliteradas em conformidade com o padrão internacional ISO 8431997

TR (2.0), com as exceções seguintes: (i) 0 " $\eta$ " foi transliterado por " $\mathrm{e}$ "; e (ii) os ditongos com " $y$ " seguem o padrão internacional ALALC 1997 (4.0).

** Alberto Bernabé é actualmente professor

de filologia grega na Universidade Complutense de Madrid, Espanha.

\section{Alberto Bernabé**}

\section{Introdução.}

\subsection{Propósito.}

$\bigcup_{\text {ma das muitas e interessantes contribui- }}$ ções que fez Alexander Mourelatos em seu livro seminal The route of Parmenides, ${ }^{1}$ foi analisar o peso da tradição épica, em especial hesiódica, no texto do filósofo. No entanto, o autor decidiu não tomar em consideração possíveis influências da tradição órfica. ${ }^{2}$ Neste sentido a obra é filha de seu tempo, da época em que predominava uma visão cética sobre o orfismo proposta por autores como Linforth e Dodds. ${ }^{3}$ Outrossim, Coxon dedicou algumas páginas aos empréstimos de Homero, ${ }^{4}$ mas descartou a tradição órfica lá onde era mais evidente, ${ }^{5}$ a atitude de Tarán ${ }^{6}$ de rechaçar de antemão, e em geral sem argumentos, todo possível vestígio órfico na obra parmenídea foi seguida por Coxon. Apesar desta falta de interesse destes grandes especialistas (e de muitos outros), ${ }^{7}$ estou convencido de que seria absurdo pensar que Parmênides, embora tenha vivido no sul da Itália em um momento histórico e em um âmbito geográfico no qual os órficos difundiam suas crenças, ignorou ou não tomou conhecimento, em absoluto, do amplo marco de referências religiosas e literárias tecidas pelos seguidores deste movimento 
paper the analysis is focused on the points of contact of the proem's imagery and ideas and literary images of the Mysteries. It is not a question of determining philosopher's beliefs, but of placing in the realm of tradition the doctrinal and poetic content expressed in this fundamental part of the poem, examining what is original in it, and trying to elucidate the proems' meaning in the poem as a whole.

KEYWORDS: Greek philosophy, Parmenides, orphism, mysteries, archaic epic

religioso ou, em geral, do âmbito dos mistérios, que formavam parte da sua tradição.

Nos últimos anos do século passado apareceram ou se publicaram testemunhos muito importantes para o nosso conhecimento do orfismo, como o Papiro de Derveni, as lâminas de osso de Olbia, uma série de documentos da Magna Grécia, as chamadas epoidaí, de interpretação obscura, mas com evidentes conexões com o mundo órfico e, sobretudo, algumas lâminas de ouro (em Hiponion, em Pelina, em Entella), ${ }^{8}$ em que encontramos nova informação sobre a presença antiga de literatura órfica, de um grupo que, em um dos casos, se denominava órfico, de práticas religiosas, e ainda, de especulação filosófica associada com essa literatura. A mudança da situação tem obrigado a um lento processo de revisão de algumas ideias dadas como boas nos anos anteriores acerca do orfismo.

No marco de tal processo, pode resultar interessante voltar a analisar os vestígios da tradição mistérica, em geral, e da órfica, em particular, no texto do filósofo de Elea. Em um trabalho anterior assinalei algumas conexões entre Parmênides e 0 orfismo, seguindo a esteira de algumas propostas de Burkert. ${ }^{9}$ Meu propósito neste trabalho será, por um lado, mais limitado; por outro, mais detido. Dado que muitos dos pontos de contato de Parmênides com o ambiente ideológico dos Mistérios, tanto no conteúdo quanto nas imagens literárias, se encontram no proêmio, centrarei minhas análises nesta parte do poema.

Ademais não pretendo mostrar que Parmênides foi órfico praticante ou que fora simpatizante do orfismo; primeiro porque, em absoluto, creio que nem do filósofo de Eléia nem de nenhum outro dos pré-socráticos pode dizer-se nada parecido, e segundo porque, mesmo que fosse, devemos distinguir, com todo cuidado, crença de doutrina; ${ }^{10}$ em outros termos, o interessante para a história das ideias não é aquilo no que o filósofo pudera crer, senão aquilo que ele expressa em sua obra como conteúdo literário e/ou doutrinal. Tampouco é minha intenção minimizar as contribuições da tradição homérica, hesiódica, ou da lírica coral em Parmênides já assinaladas, senão considerar, junto a elas, a importância dos textos órficos.

Vou utilizar "orfismo" como um termo que abarca o mistérico em geral, ${ }^{11}$ um procedimento que penso resultar legítimo se tivermos em conta que, dos Mistérios que conhecemos na Grécia, são os órficos os que deixaram um volume de textos que nos permitem realizar comparações.

\subsection{Valorações diversas do proêmio.}

As opiniões dos estudiosos sobre as motivações e o significado do proêmio são tão abundantes como diversas. ${ }^{12}$ É notável ainda que esta parte da obra é vista com desinteresse, quando não com desconfiança, por um bom número de investigadores em filosofia. ${ }^{13}$ Mas não devemos nos esquecer que para um autor grego antigo o proêmio é um componente fundamental de sua obra, a janela da qual se mostra o mais seleto do seu conteúdo. Na acertada definição de Palmer, o proêmio é "a melhor indicação do contexto cultural no qual Parmênides escolhe situar a sua mensagem". ${ }^{14}$

Por último, é importante ter em conta que é próprio do discurso dos poetas arcaicos o recurso, frequente, à ambiguidade e aos duplos sentidos, uma característica que está também frequentemente presente nos textos dos Mistérios. Os duplos ou triplos sentidos tornam o texto menos preciso, todavia mais rico de sugestões e de possibilidades abertas.

De acordo com o que foi dito, buscarei me aprofundar na natureza e nas razões das possíveis relações entre o léxico, o imaginário do proêmio, e os elementos próprios da literatura religiosa associada aos mistérios; ${ }^{16}$ Também buscarei destacar que, e como, nesta parte do poema há uma grande quantidade de detalhes que coincidem com a tradição da poesia religiosa mistérica, e como o filósofo
1. Mourelatos (1970).

2. Relações de Parmênides com o orfismo haviam sido propostas por diversos autores, como Diels (1897); Dörfler (1911), ou ainda Jaeger (1957), todavia em uma época na qual o orfismo era muito menos conhecido, e os estudiosos eram, em excesso, imaginativos quanto ao seu alcance e extensão. Mourelatos (1970, p. 42) ecoou a afirmação de Guthrie (1965, p. 11) sobre possíveis influências órficas em Parmênides: "all these echoes are on a verbal level and demonstrate not more than that Parmenides was stepped in the tradition of older and contemporary poetry". E assinala (p. 44) que "the presence of traces of Orphism (doubtful at best) ... in Parmenides' text does not warrant a revision of our conception of Parmenides' relation to traditional materials .. Parmenides is neither an Orphic, nor a latter-day shaman".

3. Linforth (1941); Dodds (1951)

4. Coxon (1986, pp. 9-11).

5. Cf. § 2.2.12

6. Tarán (1965)

7. Por exemplo, uma grande especialista no filósofo como é $P$. Curd despacha a questão com a frase: "others, including Burkert, have seen influence from the Orphic tradition" (Curd, 1998, p. 19 n. 44).

8. Sobre o orfismo, cf. uma recente e exaustiva síntese: Bernabé, Casadesús (2008), e um volume coletivo com novidades sobre este movimento: Bernabé, Casadesús, Santamaría (2010). Sobre a teogonia do Papiro de Derveni cf. Bernabé (2002 e 2007) (com bibliografia). Sobre as lâminas de Olbia cf. Bernabé (2008) (com bibliografia). Sobre as epoidaí sul-itálicas, Jordan

(1992); Bernabé (2003); Rocca (2009); Jordan-Kotansky (2011); Bernabé, no prelo 2, bem como $O F$ 830. Sobre as lâminas: Pugliese Carratelli (1993); Tortorelli Ghidini (2006); Graf-Johnston (2007); Bernabé, Jiménez San Cristóba (2008); Tzifopoulos (2010); Edmonds (2011).

9. Bernabé (2004), cap. 6; Burkert (1969; e 1999, p. 79ss.).

10. Uma frase tão rotunda quanto correta que a devo a meu colega Madayo Kahle.

11. Burkert (2007, pp. 385389) prefere falar de "mistérios báquicos".

12. Uma boa sistematização das variantes de explicação do proêmio pode ser encontrada em Couloubaritsis (1986, 
p. 80 ss.), que as divide em literais, religiosas, alegóricas racionalistas.

13. Um sintoma disso é que muitos estudos modernos começam com B1.30, ou até mesmo com o fr. 2, e consideram (sem dizê-lo) o proêmio quase como um "desagradável acidente" da tradição. Há inclusivamente maneiras sutis de renunciar 0 seu entendimento, tal como expressada por Lesher (2008, p. 473): "while the full significance of many of the details in these lines may never be known, ..." Uma posição totalmente contrári nós encontramos em Kingsley

(1999), que considera Parmênides um místico ou um hierofante, e minimiza sua condição de filósofo, no que é seguido por Gemelli Marciano (2008). Ambos, autores, rastrearam no poema fórmulas mágicas, experiências místicas e abduções. Minh relutância para com estas posições se deve a que eu não creio em abduções de nenhuma espécie místicas ou não, nem creio nas viagens da alma xamânicas, de tal forma que eu considero que todas as experiências desse jaez,

que se descrevem, derivem, exclusivamente, da imaginação do narrador, isto é, são produtos literários.

14. Palmer (2009, p. 51), um dos poucos autores modernos a quem interessa examinar o proêmio situá-lo em seu contexto cultural.

15. Cf. a atenção dada por Mourelatos (1970, c. 9) e Miller (2005) às ambiguidades do texto.

16. 0 método será semelhante ao empregado em Bernabé (2004) para os pré-socráticos, e (2011) para Platão.

17. Cf. os estudos de Herrero de Jáuregui (2010) para os empréstimos da poesia épica

à religiosa, e (2011) para os empréstimos realizados em sentido inverso.

18. Mourelatos (1970, p. 46). 19. Il. 1.1: "mênin áeide, theá" ("canta, deusa, a cólera").

20. 0d. 1.1: "ándra moi énnepe, Moûsa" ("fala-me, Musa, do varão")

21. Hes. Th. 1: "Mousáon Helikoniádon archómeth' aeídein

("pelas Musas Heliconíades comecemos nosso canto"), 22:

"haî ný poth' Hísíodon kalèn edídaxan aoidén" ("elas [as Musas] uma vez o ensinaram a Hesíodo um formoso canto")

22. Hes. 0p. 1-2: "Moûsai

Pieriethen aoidêisin kleíousai, deûte Dí ennépete, sféteron patér a reelaborou, e enriqueceu com novos propósitos, para criar um imaginário novo. 0 proêmio de Parmênides é um excelente exemplo dos empréstimos da linguagem e da narrativa poéticas às religiosas, e vice-versa. ${ }^{17}$

\section{0 proêmio.}

\subsection{Razões.}

À diferença dos milésios, que expressavam suas ideias sobre a origem e sobre a evolução das coisas como um relato, como um datum, sem especificar o modo como haviam chegado às suas conclusões, Parmênides, que expõe como pedra angular de toda a sua obra a premissa sobre o que é, e que logo argumenta detidamente sobre as consequências desta afirmação inicial, apresenta tanto uma como as outras como reveladas por uma deusa, e descreve pormenorizadamente uma viagem que o conduz à presença desta divindade.

Tampouco utiliza, como os milésios, a prosa, senão a poesia hexamétrica. Mourelatos ${ }^{18}$ tem razão em assinalar que a pergunta "why poetry?" não deve sequer fazer-se, dado que o lógos em prosa não seria uma opção viva para alguém que se situa nas coordenadas ideológicas do autor. No entanto, convém assinalar que, como veremos, o proêmio de Parmênides é também atípico para a poesia hexamétrica tradicional.

Sexto Empírico introduz o fragmento com os seguintes termos: "enarchómenos goûn toû Perì Fýseos grafei toûton tòn trópon" ("Pois bem, ao começo do Acerca da Natureza escreve [Parmênides] deste modo").

0 que segue no texto de Sexto, o verso que se refere a "as éguas que me levam", é, portanto, o primeiro do poema. 0 proêmio de Parmênides se afasta assim da tradição épica de seu tempo em uma característica fundamental: a ausência de uma invocação a uma Musa, ou uma deusa onisciente. Homero evoca a deusa a que cante, ela mesma, na Ilíada, ${ }^{19}$ e na Odisseia ele pede à musa que the fale de Odisseu. 0 poeta pede auxílio a uma instância divina para que lhe traga à memória os conhecimentos que são propriedade dela, e se mostra assim como mero receptor/transmissor da mensagem da divindade. Hesíodo começa a Teogonia exortando a si mesmo a cantar às Musas Heliconíadas e logo se introduz como personagem no poema para nos contar que seu canto foi-lhe ensinado pelas Musas, ${ }^{21}$ e, a partir daí, se constitui em narrador da história dos deuses. Em Os trabalhos e os dias também evoca as Musas de Pieria, ${ }^{22}$ mas logo se apresenta como quem tratará de contar, a Perses, uma determinada verdade, ${ }^{23}$ sem que se advirta, em demasia, a conexão entre a invocação e seu próprio dictum.

Seguindo os conselhos de Mourelatos, não colocarei, ao poema de Parmênides, a questão "why poetry?", todavia creio que é pertinente a pergunta "why not the Muse?". Com efeito, é um resultado chocante que Parmênides comece ex abrupto o poema falando de um "eu poético" que, versos a frente, resulta não ser chamado pelo seu nome, senão designado como um koûros (cf. § 2.3.2). Este eu poético é apresentado em meio a uma viagem sem antecedentes, sem a indicação de quem é, nem de como chegou a ela; e renuncia, ainda, a tradicional evocação. De outra parte, não é menos chocante que tampouco se mostre, como Hesíodo, como a fonte da mensagem instrutiva (por mais que na Teogonia Hesíodo declare que são as Musas as que o tinham ensinado).

A resposta poderia ser: Parmênides deseja indicar (ou, provavelmente, está persuadido de) que o conhecimento ao qual se referirá excede, transcende, está acima dos conhecimentos aos quais houvera podido chegar pela sua própria reflexão, e acima daqueles que puderam ser expressos por parte dos outros filósofos, tal como o aedo está convencido de que as histórias que transmite vêm de fora; renunciou a uma evocação trivial, mais própria de politesse que de crença autêntica; e elaborou uma moldura para encenar a transmissão deste conhecimento, mais próximo ao de Hesíodo em Teogonia, mas com notáveis diferenças. A primeira é que a conversação com a divindade não resultou da aparição desta, como na Teogonia, senão que o autor vai à presença da deusa por meio de uma viagem, o que implica em certa intenção de sua parte (§ 2.2.2), se bem que é certo que ele não tem nela um grande protagonismo, senão que se apresenta 
a si mesmo em um papel de todo passivo; não é sujeito de nenhuma ação, não contesta a deusa, não participa ativamente de nada: não fala, o levam, o conduzem, o instruem. ${ }^{24}$ A segunda é que esta viagem se prolonga até que, no verso 23 , se introduzam as palavras da deusa não nomeada, que será o "eu" em todos os demais versos que conservamos do poema, a fonte da revelação, do conhecimento. A terceira é que se trata de uma transmissão de conhecimento mais flexível, que a pura inspiração por parte de uma Musa. Com efeito, a deusa em muitas partes do seu discurso suscita que o que diz deve ser discutido ou fundamentado; ${ }^{25}$ considera, pois, o seu ouvinte dotado de capacidade para discernir, para algo mais que repetir sua mensagem. Trata-se, definitivamente, de um jogo revelação/composição muito mais rico que o dos modelos tradicionais, e que transcende as variantes possíveis na evocação da Musa. Esse jogo poderia explicar a estratégia de narrativa do filósofo.

0 autor marca duas etapas claramente diferenciadas nela. Uma primeira que podemos definir como "a viagem", e uma segunda, muito mais extensa que podemos qualificar como "a revelação". Entre ambas há um momento de transição (1.23-1.32) no qual a deusa saúda o recém chegado, e estabelece o "programa" do seu discurso; já ocorreu a mudança do "eu poético", mas ainda não se iniciou o conteúdo da revelação, o discurso mesmo. De alguma forma a primeira estratégia é correlata da segunda: na segunda a deusa esparziu "sinais" ("sémata") da via do ser; na primeira, o autor esparziu "palavras [oraculares]" ("fêmai") ${ }^{26}$ do caminho que o conduziu a essa via. Uma impecável composição em anel ${ }^{27}$ engata estilisticamente a parte da viagem com a da acolhida, separando essa da declaração programática da deusa (B 1.28-32).

\subsection{As fêmai da viagem.}

\subsection{1. "híppoi tai me férousin" ("as éguas que me levam") (B 1.1).}

É característico da iniciação que o iniciando deva acessar o ambiente na qual essa tem lugar, um espaço iniciático (que eu estudei em outra parte), ${ }^{28}$ na qualidade de um terreno ambíguo entre o nosso mundo e o Além, no qual frequentemente se encena uma espécie de ensaio da morte.

0 que Parmênides descreve é uma viagem de carro, mas não como as que puderam fazer os heróis homéricos, senão que uma viagem, como veremos, ultramundana. Parmênides recorre a um imaginário que compartilha com a lírica, com a menção ao carro das Musas, ao que o poeta pode subir. Há uma passagem de Píndaro que apresenta muitas coincidências com o proêmio: ${ }^{30}$

\section{ô fintis, Allá zeûxon é- \\ de moi sthénos hemiónon, \\ hâi tachos, ófra keleúthoi t' em katharâi \\ básomen ókchon, híkomaí te pròs andrôn \\ kaì génos• keînai gàr ex al- \\ lân hodòn hagemoneûsai \\ taútan epistantai, stefánous en Olympiai \\ epeì déxanto• chrè toínyn pýlas hý- \\ mnon anapitnámen autaîs• \\ Arreia-me já, Fintis, \\ o vigor das mulas \\ com presteza, para que por límpida senda}

levemos o carro, a fim de remontar-me a linhagem

destes homens, e sem dúvida elas mais do que outras,

sabem conduzir-nos pelo caminho

este, graças às coroas que em Olympia

ganharam; temos que abri-las, pois,

amplamente as portas dos hinos.

Com efeito, no texto pindárico, como no proêmio parmenídico, se fala de portas que o carro deve atravessar, se atribui conhecimento aos animais do tiro, e se lê (26) hodòn hagemoneûsai, que é correlato de (Parm. B 1.5) hodòn hegemóneuon, o que pode indicar que Píndaro (que escreveu a ode em 478) conheceu o poema parmenídeo ou que, à luz de outros paralelos, ${ }^{31}$ ambos procediam de uma tradição comum. Na minha opinião, Píndaro é a melhor mostra dos riscos de atribuir ao poema parmenídeo o caráter de uma experiência mística. Pela mesma razão, poder-se-ia afirmar que Píndaro, em um lugar próximo, passou pela experiência mística de sentir-se raptado pelas cavalarias que o levaram à linhagem dos vencedores. Mas, evidentemente, hymneíousai" ("Musas de Pieria que conferes gloria com vosso canto, vinde aqui para celebrar com hinos o pai Zeus").

23. Hes. 0p. 10: "egò dé ke Pérsei etetyma mythesaímen" ("eu

tentarei dizer palavras verdadeiras a Perses").

24. Nem sequer é chamado pelo seu nome, cf. n. 123

25. Por exemplo, B 6.2: “tá s' egò frázesthai ánoga" ("te exorto a que medites sobre esta"), B 7.5: "krînai dè lógoi polýdiren élenchon" ("discerne com a razão a prova muito argumentada"). Cf. Curd $(1998$, p. 20) que observa que para Parmênides não há conflito entre inspiração divina e pensamento racional.

26. Cf. "hodòn polýfemon", B 1.2

27. Marsoner (1976; 1978).

28. Bernabé, no prelo 1.

29. Cf. Martín Hernández (2005).

30. Pi. 0l. 6.21-29. A primeira

análise da metáfora do carro

deve-se a Fränkel (1930; 1950).

0 paralelo foi desdobrado po

Bowra (1953, pp. 42-43); cf. Cerr

(1999, pp. 96-99), que considera

que em Parmênides o carro possa

simbolizar a sophía, que inclui a

tensão até a Verdade, e a plena

possessão da técnica poética

necessária para comunicá-la.

31. Cf. ademais, Simon. Epigr.

213.3 (AP 6.213), Pi. P. 10.65, I.

2.1-2, 8.61, (de forma menos clara Thgn. 249-250), também Emp.

B 4.5 recorrerá a uma imagem semelhante. Cf. Bowra (1953, pp. 41-43); Martinelli (1987) e Cerri (1999, p. 98 n. 133), quem trará mais passagens e bibliografia.

32. Daqui por diante, $0 F$, seguido de um número, indica a edição

dos fragmentos órficos de Bernabé (2004-2007)

33. Do carro. Cf. West (1983, pp. 214-215), quem assinala as conexões entre o carro de Fanes e carro do Sol.

34. Coxon (1986, p. 157)

Gemelli Marciano (2008, p. 29 e n. 20) o considera relevante desde uma perspectiva mistérica, e cita o paralelo do hCer. 18 A lição do manuscrito é -oisi, mas Gemelli Marciano propõe corrigi-la, baseando-se na leitura athanáta[isi] da versão órfica do hino (OF 389). 0 argumento pode inverter-se; o poeta órfico que adapta o hino homérico mudou o sexo das cavalarias para adaptá-las à tradição. Cf., assim mesmo, Cerri (1999, p. 101, e n. 140). 35. Cf. o paralelo, na 0d. 15.339 pémpsei d' hóppei se kradíe thymós te keleúei, citado por Diels e recolhido por Coxon (1986, p. 
157), ainda que neste caso o verbo apareça no indicativo. Sobre thymós em Homero, cf. Megino (2002), com bibliografia. Cf., ainda, Conche (1996, p. 44). 36. Como assinala Cordero (2005, p. 38), quem, para além de recolher as principais propostas anteriores na n. 7, apresenta 0 paralelo de 0d. 12.57-58 no qual há dois caminhos e Odisseu terá que eleger um deles com a ajuda de seu thymós (hoppotérei dé toi hodòs éssetai, allà kai autòs/ thymôi bouleúein). 37. 0 proêmio das Ephemerides (OF 559.1-4). 38. Cf. as observações de Kranz (1916), Marsoner (1976-1978), e de Cordero (2005, p. 41). 39. Cf. Hes. Th. 22 citado em não é assim; o grande poeta beócio utiliza uma pura imagem literária tradicional. Deve-se acrescentar que a imagem do carro que realiza uma viagem fora do mundo também se encontra na literatura órfica: nas Rapsódias nos é apresentado Fanes, que uma vez tendo deixado o governo do cosmos, realizando uma viagem celeste em carro, da qual mantém a sua vigilância sobre os acontecimentos do mundo:

OF 172 I (Herm. in Phdr. 142.13 Couvr.) ${ }^{32}$

Prótoi gàr toútoi (sc. tôi Fáneti) he theología paréchei toùs híppous.

Foi a ele (a Fanes), o primeiro ao qual a teologia atribuiu cavalos.

OF 173 (Procl. in Plat. Alcib. 103 a [54 Segonds])

hoîsin epembebaòs daímon mégas âen ep' íchne

Em cima dele, ${ }^{33}$ o grande daímon está sempre fazendo sua ronda.

Platão desdobrará a mesma imagem de uma viagem de carro escatológica no Fedro (e, tampouco, imagino o filósofo ateniense abduzido em uma experiência mística). Tal relação de continuidade temática não escapou da análise do comentarista Hermias:

OF 172 (Herm. in Phdr. 122, 19 Couvr.)

ou prôtos dè ho Pláton heníochon kai hípous parélaben, allà prò autoû hoi éntheoi tôn poietôn, Hómeros, Orfeùs, Parmenídes • all' hyp' ekeínon mèn háte enthéon áneu aitías eíretai• enthousiôntes gàr élegon.

Platão não foi o primeiro que utilizou a cocheira e os cavalos, senão que antes dele o fizeram os poetas inspirados pelos deuses: Homero [Il. 8, 438], Orfeu e Parmênides. Contudo, aqueles o disseram sem uma causa, por estarem inspirados, pois o diziam enquanto possuídos pelo entusiasmo divino.

Hermias comete um erro, pois, dado que as Rapsódias são muito posteriores ao filósofo ateniense, elas não poderiam ser a fonte dele. No entanto, é sabido que os poetas órficos trabalham reelaborando constantemente a sua tradição, o que não impossibilita que o tema do carro celeste tenha aparecido em passagens de uma Teogonia órfica mais antiga, que haveria sido reelaborada pelo poeta das
Rapsódias. Além disso, em considerando que a Olímpica VI está dedicada a Hagesias, um siracusano, não é impossível que situemos em um poema épico religioso da Magna Grécia a origem da tradição na qual se basearam Píndaro e o filósofo de Eléia, a qual pode ser conhecida, mais tarde, por Platão.

Observo, en passant, que se trata de éguas, e não de cavalos. A presença do feminino é totalmente predominante no proêmio. ${ }^{34}$

\subsection{2. "hóson t' epì thymòs hikánoi" ("tão distante quanto alcance 0 ânimo") (B 1.1).}

thymós é um conceito tradicional da psicologia da épica, que abarca desejo e vontade, ${ }^{35}$ mas, além disso, inclui certa capacidade de discernir. ${ }^{36} 0$ caminho da deusa leva até onde se queira que ele leve, e se requer ânimo e vontade para empreendê-lo, o que também é resultado de uma escolha consciente.

Encontramos um testemunho, de thymós, similar a esse em âmbito mistérico no proêmio de um poema órfico tardio, que segue, no entanto, as convenções da transmissão iniciática de conhecimentos: ${ }^{37}$

pánt' edáes Mousaîe theofradés. Ei dé s' anógei thumòs eponymías ménes katà moîran akoûsai, ktl Tudo apreendestes profético Museu; mas se te impele

o ânimo a escutar, em ordem, os sobrenomes da lua etc.

Como em Parmênides, o iniciando precisa de um ímpeto prévio, de um desejo de adquirir o conhecimento iniciático.

\subsubsection{Tempos, modos, aspectos e reiterações verbais.}

Convém analisar com cuidado o interessantíssimo jogo dos tempos, modos e aspectos verbais do começo da passagem. ${ }^{38}$

férousin está no presente do indicativo. E esse não é o presente histórico porque tal uso é alheio à 
tradição épica. De tal modo que, ou bem a) a viagem se atualiza a cada vez em que o poema é lido, ou b) se trata de um presente durativo. Neste segundo caso, pode ser interpretado que b1) Parmênides quer indicar que continua repercorrendo esta senda, ou b2) as éguas o levam habitualmente, em contrapartida com um modo especial de levá-lo produzido na situação extraordinária descrita pelo aoristo. 0 mais simples é que se trate de b2). 0 optativo hikánoi indica aqui frequência indefinida, o que, na opção b1) poderia indicar a ideia de que é um caminho pelo qual marcha com frequência, entretanto, a opção b2) indicaria que as éguas o levam habitualmente por ali, onde ele quer, frente ao modo passivo em que é levado na ocasião extraordinária. ${ }^{40}$ 0utros presentes são usados em descrições de objetos (indicando onde, ou como eles estão) de modo independente da viagem: férei (B 1.3), eisi (B 1.11), échei (B 1.14). Equivalentes aos presentes, quanto ao sentido, são os perfeitos, ainda que agreguem a noção de estado: eidóta (B 1.3), ${ }^{41}$ plêntai (B 1.13), e areróte (B 1.20).

Ao contrário, os episódios fundamentais do percurso pela senda da deusa se expressam em aoristo (ação terminada no passado): bêsan (B 1.2), peîsan (B 1.15), ${ }^{42}$ poíesan (B 1.18), hypedéxato (B 1.22), hélen ... fáto (B 1.23). Equivale a eles, funcionalmente, o optativo sperchoíato (B 1.18). ${ }^{43}$

As ações contemporâneas às narradas em aoristo, mas que têm uma duração, isto é, que transcorrem no marco temporal em que se situam as ações em aoristo, se expressão no imperfeito, ${ }^{44}$ ou no particípio presente, com valor durativo: pémpon, ágousai (B 1.2), férómen ... féron (B 1.4), titaínousai ... hegemóneuon (B 1.5), híei (B 1.6), aithómenos ... epeígeto (B 1.7), échon (B 1.21), proseúda (B 1.23).

Por último, os particípios de aoristo, indicam ações anteriores à expressada pela principal: prolipoûsai (B 1.9), osámenai (B 1.10), parfámenai (B 1.15), anaptámenai (B 1.18), eilíxasai (B 1.19).

Em resumo, quanto ao uso dos verbos, Parmênides nos diz que as éguas que o levam habitualmente onde ele queira, o levaram uma vez por uma senda extraordinária, na qual sucederam uma série de coisas em cenários que são descritos de uma certa maneira.
Não menos interessante é a reiteração de verbos, que significam "levar", no princípio do proêmio, o que levou Kingsley ${ }^{46}$ a considerar que eram parte de uma performance mágica. Penso que é mais aceitável, além de entender que, em grande medida, a reiteração serve para estruturar o relato, interpretá-la em termos iniciáticos: o filósofo parece insistir na indicação de que é este o caminho, e não outro, que conduz ao lugar adequado. Nas lâminas órficas também se insiste na ideia de que a senda percorrida pelos iniciandos deve ser uma em particular, e apenas essa; tal como se vê na fraseologia de um texto muito próximo, em lugar e em data, do poema parmenídeo, a lâmina de Hiponion: ${ }^{47}$

kaì dè kaì sý piòn hodòn érchea<i> hán te kaì álloi mústai kaì bákchoi hieràn steíchousi kle<e>inoí

$E$, uma vez que bebas, tomarás por caminho aquele no qual, também, os outros

iniciados e bacantes caminham gloriosos, o caminho sagrado. ${ }^{48}$

A inicianda possuidora da tábua vai por um caminho que é precisamente o que (hán te) têm percorrido os demais iniciados; o que quer dizer que os não iniciados percorreram outros distintos, e que não chegaram ao lugar especial e reservado para eles. 0 mesmo ocorre em outra lâmina de Pelinna, um pouco posterior, IV a.C. (OF 485.7):

Kaì sý mèn eîs hypò gên telésas háper ólbioi álloi.

E tu irás sob a terra, cumpridos os mesmos ritos que os demais felizes.

A inicianda tem cumprido os mesmos ritos que (háper) têm convertido em felizes os iniciados, e vai ao mesmo lugar ao qual vão aqueles que o têm feito adequadamente. Em ambos os casos, o caminho é um caminho para o Além subterrâneo, o Hades órfico.

\subsection{4. "hodòn ... polýfemon" ("caminho de múltiplas palavras") (B 1.2).}

Parmênides está falando, pois, de um caminho, mas de um caminho que é de palavras
40. Tarán (1965, p. 9s), com bibliografia, assinala que é pouco provável que se trate do thymós das éguas; Coxon (1986, p. 157) 41. Mas, sobre esta forma cf. $\S 2.6 .6$.

42. Verbo do qual depende a subordinação hós ... óseie.

43. Cf. § 2.2.7.

44. Nos termos de Fränkel (1968, p. 159), recolhidos por Tarán (1965, p. 10), o imperfeito torna atual o que antes foi dito em geral. Contra Conche (1996, p. 44)

45. Ainda que seja um particípio presente, o caráter defectivo do verbo e, em especial, o uso de éfe com valor de aoristo torna preferivel sua inclusão neste grupo.

46. Kingsley (1999, p. 119). Gemeli (2008, p. 32) considera que Kingsley "has demonstrated specifically ... [that] repetition is a well known method used in mystical texts for bringing about another state of consciousness", o que pode ser certo; mas a repetição é, também, possui outros múltiplos usos, incluindo a aprendizagem da tábua de multiplicar.

47. OF 474.15. Cf. BernabéJiménez San Cristóbal (2008, pp. 50-53).

48. Observe-se, também aqui, o uso dos tempos: o futuro "tomarás" (o iniciando concreto) em contraposição com o presente "caminham" (referindo-se aos outros iniciados, a todos os iniciados de antes, de agora e de depois). 
49. Cf. Untersteiner (1956) 50. Cordero $(2005$, p. 37). 51. Cf. em Pi. I. 8(7).64 "thrênos polýfamos", e o estado da questão apresentado por Ranzato (2011,

52. Cf. o completo, mas não conclusivo, estado da questão em Palmer (2009, p. 51 n. 1), bem como em Tarán (1965, p. 10), cuja tradução, "resounding", também, é ambígua.

53. Cordero $(2005$, p. 41) cita o paralelo de S. OT 86 "tín' hemin hékeis toû theoû fémen féron;"

("qual revelação do deus vem trazer-nos?"); Édipo, a Creonte, que havia ido consultar o oráculo.

Miguel Herrero me indicou o paralelo de 0d. 20.100, e 105, no qual Odisseu pede um presságio

(féme) a Zeus, e esse o envia.

54. Bowra (1953) anota que no Himno órfico a Zeus (OF 243.15)

se lê a expressão "theôn hodo

ouraniónon" ("caminhos dos deuses celestiais"), e apresenta o, significativo, paralelo de Pi. 0 . 2.70 "Diòs hodón", que tampouco

é um caminho deste mundo, e que está reservado para as almas escolhidas.

55. Deichgräber (1958, pp. 6 , 7, e 37)

56. Gomperz (1924, p. 4 n. 9) 57. Morrison (1955, p. 60 ); Mansfeld (1964, pp. 244-247); Gómez-Lobo (1981); West (1983, p. 109); Palmer (2009, p. 58) que assegura: "the first reason for making this identification is simple and straightforward, - the daughters of Helios bring Parmenides to the halls of Night ... and the goddess who greets him upon his arrival there welcomes him to 'our home'". 0 problema é que, para que esteja certa esta taxativa asserção necessário admitir a proposta interpretativa, de que as Helíades vão buscar Parmênides e o traze

de volta (cf. § 2.2.8), o que não resulta tão evidente como o parece ao autor.

58. Guthrie $(1965$, p.10)

Hölscher (1969, p. 74). 59. Mourelatos (1970, p. 161) 60. Pugliese-Carratelli (1988) Sassi (1988, p. 393) 61. Cerri (1999, p. 107s); Kingsley (1999, pp. 92-100); Gemel Marciano (2008)

62. Tarán (1965, p. 16); Conche (1996, p. 56).

63. Bowra (1953, p. 47) sugere: "this experience is unique to him (sc. Parmênides), and therefore he can hardly attribute it to a goddess shared with other men". cf. § 2.3.1. (polýfemon), uma senda de conhecimento. ${ }^{49}$ Este caminho é o reflexo do caminho conceitual percorrido no relato da deusa, que na continuação do poema segue falando de "caminhos". Como assinala Cordero: "para Parmênides o conhecimento se obtém como uma consequência de um 'percurso', de uma 'viagem', de um decurso conceitual, isto é, graças a um método".

Neste contexto temos de situar o adjetivo polýfemos, que pode ter um sentido ativo, ou passivo. Na Odisseia 22.376 é dito de um aedo no sentido de que "conta muitas lendas" (ativo), enquanto que em 2.150 se aplica a uma agorén "na qual se dizem muitas coisas" (passivo). Tem-se discutido aqui, se o sentido é ativo, "que abarca, ou transmite múltiplas palavras", "significativo", ou passivo, "do qual se dizem múltiplas palavras", "famoso". ${ }^{52}$ Sem prejuízo de que Parmênides, uma vez mais, deseje expressar-se de um modo ambíguo, faz sentido que o caminho, que conduz à deusa, esteja povoado de fêmai (no sentido de "palavras oraculares"), ${ }^{53}$ isto é, que servem para preparar para o conhecimento dos que serão, mais adiante, os "sémata" ("sinais") do que é.

\subsection{5. "hodòn .../daímonos" ("caminho .../da deidade") (B 1.2-3).}

Parmênides chama esta via de caminho "da deidade", o que quer dizer que não é uma via humana (cf. B 1.27 “ap' anthrópon ektòs pátou estín", "está fora do pisado pelos homens"), não é uma via deste mundo. ${ }^{54}$ Algo muito semelhante pode dizer-se do "caminho sagrado" ("hodòn ... hierán") ao qual se refere a lâmina órfica de Hiponion (OF 474.15) na passagem citada em $\S$ 2.2.3, que tampouco está neste mundo, senão no Além, e sobre o qual o percurso é informado aos iniciandos.

Quanto à daímonos, uma das vexatae quaestiones do poema é a identidade da deusa. Como candidatas, foram propostas Justiça (Díke), ${ }^{55}$ Dia $^{56}$ Noite (divindade sábia nas cosmogonias órficas, à qual vão consultar diversos deuses), ${ }^{57}$ a Musa de Parmênides, ${ }^{58}$ Persuasão (Peithó), ${ }^{59}$ Mnimosýni (deusa da Memória, que também tem um importante papel em alguns textos órficos porque permite ao iniciado manter, no Além, o conhecimento que aprendeu na iniciação), ${ }^{60}$ ou inclusivamente a própria Perséfone, a deusa infernal, ${ }^{61}$ entre outros nomes. Na minha opinião trata-se de uma discussão estéril. Se o poeta não disse o seu nome é porque não quer dizê-lo. ${ }^{62}$ Se o fizesse, a situaria em um espaço religioso concreto, conhecido, tradicional. E isso é o que precisamente não quer fazer. ${ }^{63} \mathrm{Re}-$ paremos, também, no fato de que tampouco ela chama Parmênides por seu nome.

Outra coisa distinta é que a visita da deusa tem muitos pontos em comum com a visita de Zeus à Noite no Papiro de Derveni (cf. § 2.2.9).

\subsection{6. "férei eidóta fôta" ("ao homem que sabe") (B 1.3).}

Se é um caminho "no pisado pelos homens" (B 1.27) eidóta fôta não pode querer dizer "o homem que sabe o caminho" como postula Tarán; ${ }^{64}$ o verbo férei está no presente. Se apenas levasse ao homem que já conhece o caminho, porque já o percorreu, como poderia alguém percorrê-lo pela primeira vez? Ademais, não é Parmênides que conduz o carro, senão as Helíades. Sim, poderia significar "o homem que já conhece", porque é um caminho que tem a ver com o conhecimento, mas não com um conhecimento qualquer, senão com o iniciático, e se situa no âmbito da revelação religiosa; ${ }^{65}$ isso nos levaria, novamente, à conexão com a passagem da lâmina de Hiponion (§ 2.2.3), o viajante se apresentaria como um mýstes, e a viagem seria já um símbolo da aquisição de conhecimento. No entanto, me parece que, sem perder a conexão semântica de eidóta com o saber iniciático, é mais provável entendê-lo como um predicativo de resultado; o caminho leva um homem "para que saiba", para que, como resultado da sua passagem por ele, "seja conhecedor". ${ }^{66}$

0 caminho (ou a deusa, o relativo "hè" de B 1.3 é ambíguo) leva o mortal para que seja conhecedor com "respeito a quanto há" ("katà 
panta<tá>t $\left.t^{\prime} i^{\prime \prime}\right){ }^{67}$

\subsection{7. "aithómenos" ("o vermelho") (B 1.7), "sperchoíato" ("urgiam") (B 1.8).}

Frente ao valor de hikánoi no verso 1 (§ 2.2.2.), Mourelatos argumenta convincentemente contra o sentido iterativo do optativo sperchoíato nesta passagem, e assinala que em Homero ${ }^{68}$ a fórmula designa a simples concomitância das ações. Creio que tem razão; o que distingue o optativo hikánoi (B 1.2) desse é que o primeiro está em uma subordinada a uma principal no presente: “me levam [habitualmente] ... tão distante quanto alcance meu ânimo" (em cada ocasião), e o segundo a uma principal no passado: "me levavam quando se aceleravam" (sc. desta vez, na viagem extraordinária). ${ }^{69}$

Um eixo ao vermelho é coerente com a possibilidade de uma viagem no carro do Sol (cf. 2.2.8), mas também este fato, a menção de que as rodas aceleram o carro, e o advérbio apteréos (B 1.15) podem indicar que a viagem não se faz em um marcha tranquila, senão que acelerada. ${ }^{70}$ Por um lado isso pode significar que é uma viagem especial, na qual o carro vai a uma desusada velocidade, mas é curioso, que nas viagens dos iniciados, como o que se descreve nas lâminas de ouro órficas, parece haver uma especial urgência ("ôka" OF 474.11, "kaì tót' épeita" OF 476.11). No caso das lâminas trata-se de que o defunto iniciado deve atuar rapidamente para não errar seu caminho no Além quando acaba de morrer. A este respeito, Segal indica, em seu comentário à lâmina de Pelinna, o contraste entre urgência inicial e calma final, com palavras que poderiam aplicar-se perfeitamente ao proêmio parmenídeo. ${ }^{71}$ Um novo matiz que sugere um âmbito escatológico para a nossa passagem.

\subsection{8. "Heliádes koûrai" ("As Filhas do Sol") (B 1.9).}

As Filhas do Sol são personagens pouco representativas na mitologia grega. ${ }^{72} \mathrm{Na}$ maioria das fontes, seu papel se reduz a terem sido acompanhantes de seu irmão, Faetonte, quando esse usurpou o posto de cocheiro, e de haver dado lugar a diversos feitos maravilhosos como resultado da sua dor (conversão em álamos, suas lágrimas em âmbar, etc.). Não conheço melhor justificação da sua presença no poema que a apresentada por Cordero, ${ }^{73}$ segundo o qual, o fracasso de Faetonte se deveu a duas razões: não teria direito de ter feito o que fez (usar o carro); e ele empreendeu a viagem sem conhecer o caminho e sem um guia. Faetonte seria então a imagem negativa do viajante parmenídeo, que conta com o aval da justiça e com a orientação de condutoras que conhecem a direção. Assim, pois, temos de supor (com uma boa quantidade de outros estudos) ${ }^{74}$ que esta viagem se faz no carro do Sol, o que parece sugerir, por um lado, que a viagem é celeste, e por outro, que há uma garantia da verdade, dado que o Sol ilumina tudo, e tudo vê. ${ }^{75}$

É importante destacar que a poesia órfica converte o Sol (muitas vezes identificado com Apolo) na origem da revelação, este é o caso dos versos das Rapsódias órficas, em cujo proêmio podemos ler (OF 102):

Ô ánax, letoûs hyié, hekatebóle, Foîbe krataié, panderkés, thnetoîsi kaì athanátoisin anásson, Hélie chryséaisin aeirómene pterýgessin,

Dodekáten dè ténde parà seîo éklyon omfén,

seîo faménou, sè d'autón, hekebóle, mártyra theíen.

Soberano, filho de Leto, certeiro arqueiro, Febo poderoso,

onividente, soberano de mortais e imortais,

Sol, elevado por asas de ouro,

esta, com efeito, é a décima segunda revelação que te ouço,

porque tu tens falado. E a ti mesmo, arqueiro, poderia eu tomar-te por testemunha.

Além do mito recolhido por Esquilo na tragédia, perdida, Basárides, segundo o qual Orfeu se fez adorador do Sol, ${ }^{76}$ há um amplo material que indica que houve entre os órficos um grande desdobramento do culto ao Sol desde muito cedo. ${ }^{77}$
64. Tarán $(1965$, p. 12). 65. Bowra (1953, p. 50-51); Untersteiner (1958, p. LXIII); Coxon (1986, p. 159). Cf. ainda, OF 1, cit. em § 2.2.11.

66. Conche (1996, p. 46). Cosgrove (2011) considera que eidóta fôta se pode também entender como um particípio substantivado com objeto direto, e fôta como acusativo da palavra quase homófona que significa "luz", mas não parece possível que um sintagma como esse tenha sido entendido de outro modo por um grego da época.

67. Conjectura de Suárez de la Torre (2010), que na minha opinião resolve com bastante eficácia este locus disputatus. 68. Il. 19.317, e 0d. 13.22 . Mourelatos (1970, p. 17). 69. Conche (1996, p. 47) interpreta o optativo em sperchoíato como a indicação de que se trata de uma ficção. Não me parece, provável, uma "descarga" tão notória da tensão criada no que o poeta apresenta a todo o momento como uma verdade.

70. Conche (1996, p. 46s.) indica o sentido do verbo, contudo sem considerá-lo significativo.

71. Segal (1990, p. 414) sobre OF 485-86: "these markers of urgency contrast with the calmer mood of the last line, the assurance of the bliss that awaits the addressee. This movement from intensity to reassurance constitutes the dynamics or the implicit drama of the represented event".

72. Cf. Coxon (1986, p. 160); Palmer (2009, p. 56). Este último autor considera, a partir de uma série de textos mesopotâmicos, que o sol viajaria pela noite pelo mundo subterrâneo. Mas é bem conhecido que o modelo testemunhado no mito grego é que o Sol descansa pela noite em um caldeirão que, levado pela corrente do Oceano, o conduz novamente ao Levante, cocheiro e cavalos dormem, cf. Stesich. S 17 Page, Mimn. 12 West, e representações figuradas em Yalouris (1990, p. 1015 nn. 99-100). Sobre a passagem de Estesícoro cf. sem embargo § 2.2.9.

73. Cordero (2005, p. 40); Ranzato (2011, p. 8) (“desejando apresentar o kouros como uma sorte de 'afortunado Faetonte'"'). Cf. a aproximação de Bowra (1953, pp. 45-46), e as interessantes apreciações de Cerri (1999, pp. 100-101).

74. Como os de Conford (1939, p. 30), e de Guthrie (1965, p. 24). 


\subsection{9. "prolipoûsai dómata Nyktós/ eis fáos" ("deixada para trás a morada da noite para dentro da luz") (B 1.9-10).}

Tem-se discutido à saciedade a direção da viagem. E uma das chaves do problema consiste na relação existente entre pémpein, prolipoûsai, e eis fáos. Se eis fáos se relaciona com pémpein, as Helíades levariam o koûros da escuridão à luz na viagem que está sendo descrita. ${ }^{78}$ Se ao contrário pémpein está sendo tomado em sentido absoluto, e eis fáos está relacionado com prolipoûsai, poderia entender-se que as Helíades realizaram o percurso da escuridão para a luz, mas não estaria especificado necessariamente que fora na viagem que está sendo descrita, senão que poderiam tê-lo feito antes, para buscar o koûros. Esta interpretação é a de Burkert e Palmer,79 que traduz "having earlier left the halls of Night for the light", e pensa que as Helíades saíram da Morada da Noite para recolher Parmênides e retornar novamente. Para que a frase fosse clara se requereria um indicador como prósthen; e a referência a uma viagem de volta requereria outro indicador como pálin, mas não temos nem um nem outro. Entretanto, Ferrari ${ }^{80}$ interpreta que Parmênides se refere ao momento no qual já havia sido iniciado pela Noite, e descreve a viagem de saída, do leste ao oeste, seguindo a rota do sol. É evidente que se a passagem pode ser interpretada de formas tão diversas, é porque é ambígua. E, como noutros pormenores do proêmio, penso que tal ambiguidade foi desejada por Parmênides, que descreve sua via-

75. Cerri (1999, p. 97) considera que Parmênides substitui as Musas pelas Helíades porque o seu relato não é místico, senão que um relato científico, entretanto Ranzato (2011, p. 15) assinala que Parmênides quer transmitir a ideia de que o kouros percorre um caminho de inspiração divina, mas diferente do tradicional. 76. Cf. p. $138 s s$, da edição de

77. Cf. OF 536-5 Radt.

78. Cf. Cordero (2005, p. 42). 79. Burkert (1969); Palmer (2009, p. 53).

80. Ferrari (2003) 81. Stesich. S 17 Page. 82. OF 487.1 83. OF 339 . gem ao Outro Mundo com características diversas, e até mesmo contraditórias, tomadas de tradições, também, diversas.

Em todo caso, gostaria de adicionar um par de pormenores interessantes:

0 primeiro deles é que o feito das Helíades, de saírem das moradas da Noite, coincide com uma descrição de Estesícoro: ${ }^{81}$

âmos d' Hyperionída ìs

dépas eskatéba <pag>chrúseon ó-

fra di' Okeanoîo perásais

afíkoith' hiarâs potì bénthea vy- ktòs eremnâs

potì matéra kouridían $t^{\prime}$ álochon paídas te fílous.

Quando a força do Hiperiônida

na taça toda de ouro embarcou

para, uma vez atravessado o 0ceano,

chegar ao profundo da noite sagrada,

tenebrosa,

junto a sua mãe, sua legítima esposa, sua legítima esposa,

e seus filhos.

0 sol embarca no 0cidente (com o carro e os cavalos) em uma enorme taça de ouro para, uma vez percorrendo a correnteza do Oceano em volta da Terra, chegar ao Oriente, e descansar ali na morada da Noite até o amanhecer, no qual voltará a montar no carro para percorrer o caminho do dia. 0 segundo é que a conexão proleípo e fáos/fôs apenas é encontrada em outras quatro passagens fora do texto parmenídeo do qual nos ocupamos, e em todas há uma forte conexão com o mundo dos mortos:

a) Em uma lâmina órfica de Turios, na qual a alma marcha ao Além deixando a luz do sol: ${ }^{82}$

All' hopótan psychè prolípei fáos aelíoio,

Mas quando a alma deixa para trás a luz do sol.

b) Em uma passagem das Rapsódias, na qual se indica a sorte das almas depois da morte, mas em um contexto no qual se está falando de metempsicoses: ${ }^{83}$

hoppóte d'ánthropos prolípei fáos eelíoio, psychàs athanátas katágei Kyllénios Hermês gaíes es keuthmôna pelórion.

Mas quando um homem deixa para trás a luz do sol, suas almas imortais são levadas, em baixo, por Hermes Cilenio

à descomunal cavidade da terra.

c) Em um epigrama da Anthologia Palatina no qual se faz referência à viagem de Odisseu ao mundo dos mortos (AP 9.459.4):

pôs $d^{\prime}$ étle prolipêin hieròn fáos

Como ousaste deixar para trás a luz sagrada? 
d) Em Eurípedes (Alcestes de 122-128) há uma passagem especialmente curiosa porque 0 caminho é o inverso, embora colocado como um adynaton:

Móna d'án, ei fôs tód' ên

ómmasin dedorkòs

Foíbou paîs, prolipoûs'

êlth' àn hédras skotíous

Háida te pýlas•

dmathéntas gàr aníste.

Apenas se esta luz

pudesse ver com os seus olhos

o filho de Febo [sc., se Asclépio estivesse vivo], depois de haver abandonado

as moradas sombrias

e as portas do Hades devolvê-lo;

pois aos dominados pela morte os reavivava.

Devo ainda adicionar uma passagem muito reveladora do Hino a Deméter (é difícil encontrar um contexto que seja mais iniciático que o desse hino) ${ }^{84}$ no qual encontramos esse mesmo caminho inverso; Zeus encarrega Hermes de ir ao mundo dos mortos:

ófr' Aíden malakoîsi paraifámenos epéessin

hagnèn Persefóneian apò zófou eeróentos

es fáos exagágoi.

Para que, depois de convencer Hades com palavras suaves,

$$
\begin{aligned}
& \text { a sagrada Perséfone da nebulosa escuridão } \\
& \text { trouxesse à luz. }
\end{aligned}
$$

Não deixa de ser curioso que também nesta última passagem a persuasão, do soberano do Além, se faça necessária para que a viagem seja permitida (cf. B 16 peîsan epifradéos), provavelmente porque esta representa uma transgressão do equilíbrio cósmico e da ordem normal das coisas. ${ }^{85}$ Sem dúvida predominam os elementos catabáticos no proêmio, mas estão consideravelmente velados pela ambiguidade, sem que Parmênides precise se o caminho é de ida ou de volta, subterrâneo ou celeste. Também há conotações claramente iniciáticas nas quais se relacionam a luz, a vida e o conhecimento. ${ }^{86} 0$ caminho de Parmênides, como o de Perséfone no hino, e como o que está vedado a Alcestis, é um caminho que tem haver com o Além, mas que também sugere a volta, a "direção contrária", uma viagem, pois, inabitual, em uma imagem especial, que o poeta criou com elementos da tradicional. Não é um espaço real, senão um espaço ambíguo, o da iniciação, que em vão buscaríamos na geografia.

Tarán afirma que "não há nada no contexto que sugira uma influência da concepção órfica da Noite" ${ }^{87}$ mas sim o há: a relação da Noite com a transmissão de conhecimento, que se encontrava nas Rapsódias, mas que agora sabemos que estava já na Teogonia do Papiro de Derveni, que é contemporânea, ou anterior ao filósofo. Neste último poema se conta que Zeus vai realizar a nova criação do mundo, e vai à Noite, dado que a deusa, como primeiro ente, tem um conhecimento completo da realidade das coisas: ${ }^{88}$

\section{[Zeùs mèn ...}

hêsto] panomfeúousa [theôn] trofòs ambrosíe Nýx•

$$
\text { ... chêsai ... ex a[dýtoi] }
$$

$0 \ldots$

[hè d'] échresen hápanta tá hoi thé[mis ên anýsas] thai,

Hos àn é[choi ká]ta kalòn hédos nifóentos Olýmpou.

E Zeus [chegou à caverna,

onde]

se sentava Noite, que tudo prediz, imortal enfermeira dos deuses.

... vaticinar desde o mais recôndito.

E ela vaticinou tudo quanto o era lícito alcançar:

Como ocuparia a bela sede do nevado Olimpo.

Além disso, fáos conota a ideia da verdade como "iluminação", que encontramos no mundo órfico, por exemplo, na lâmina de Turios, em um contexto iniciático, (0F 492.9) "fáos es fréna" (“luz, a inteligência"). E, em um fragmento de Eurípides ${ }^{89}$ lemos:

sý gàr én te theoîs toîs ouranídais

skêptron to Diòs metacheirízeis

chthoníon th' Haídei metécheis archês.

pémpson $d^{\prime}$ es fôs psychàs enéron.

Pois tu, entre todos os deuses celestes,

Administras o cetro de Zeus.

E compartilhas com Hades o poder subterrâneo.
84. HCer. 336-338. Destacado por Pérez de Tudela (2007, p. 122); Gemelli Marciano (2008, p. 34) 85. Ranzato (2011, p. 32). 86. Coxon (1986, p. 162). Cf. Palmer (2007, p. 57): “the language of the proem associated him (sc. the travelling) ... with initiates into mysteries and with the souls of the dead travelling to the underworld".

87. Influência proposta por Kern (1890, p. 174).

88. OF 6 (P. Derveni col. X 9, XI 1, XII 1). Sobre vaticínios da Noite nas Rapsódias cf. OF 113, 219,

237 (em que é visitada por Zeus), 238, 251. Sobre "os caminhos da noite e do dia" cf. § 2.2.11. 89. Fr. 912.6-9 Kannicht. 90. Macías (2008, p. 1211). 
Envia a luz às almas dos mortos.

Como assinala Macías, ${ }^{90}$ a luz tem aqui um 91. Cf. Dubois (1996, p. 95, e 156)

92. Como assinala, acertadamente, Cerri (1999, p. 100)

93. Cf. Coxon (1986, p. 161). D sua parte Bowra (1953, p. 45) afirma: "a detail indicative of almost indecent haste which surely comes from some old story".

94. Goméz Lobo (1999, p. 31); Cordero (2005, p. 45).

95. Isso me parece mais verossímil que considerar que uma metáfora da neblina matinal através da qual sai o sol (!)

como quer Palmer (2009, p. 57)

É interessante a contraposição entre a expressão de Parmenides e Hes. Th. 9-10 (nos mesmos versos em ambos os poemas) segundo a qual, as musas vêm "kekalymménai eéri pollôi/ennýchiai" ("veladas por espessa neblina, noturnas"), assinalada por Cerri (1999, p.

103) e desenvolvida por Ranzato (2011, p. 11)

96. Cf. Coxon (1986, p. 161), que aponta que pode haver uma conotação de que os seres humanos em geral estão como que encerrados no Tártaro. Não entendo a afirmação de Tarán (1965, p. 13) "there is no need to identify entha".

97. OF 1, cf. Bernabé (1996). 98. Pace Tarán (1965, p. 14), que nega que isso indique localização das portas. Mas "aithérios" em grego não significa outra coisa senão "que está no éter", ou "no céu", cf. A. R. 3.159-60 "autàr épeita pýlas exélythen Oulýmpoio / aitherías". Em Nonn. D. 38.192 Faetonte pede a seu pai, o Sol, "o carro de fogo, e o curso dos cavalos que vão pelo céu" ("éiteen émpyron hárma kai aitherion drómon híppon"), cf. 42.35 "pelo caminho celeste", "di' aitheríes dè keleúthou"; cf. Nonn.

D. 6.203 "aithérion keládema pýlai kanáchizon Olýmpou" ("as portas do Olimpo ressoaram com o bater etéreo"). Apenas o part pris do autor, que começa vários de seus comentários afirmando que "não há" influência órfica, pode levar a negar o evidente. Ele é seguido por Conche (1996, p. 49): “certes, le voyage de Parménide ne correspond aucunement à une expérience efective", algo que va de soi; ninguém afirmou que Parmênides atravessou realmente umas portas no céu. 99. Il. 5.748-754. duplo significado: por um lado, o conhecimento, e por outro, a vida; o conhecimento que revelou a divindade permite a liberação da alma, e seu acesso à verdadeira vida.

Também é possível ajuntar uma inscrição de Olbia, de alguns membros do Tíaso de Bóreas, com prováveis conexões órficas, e com claras semelhanças às lâminas de osso $(\S 2.3 .6),{ }^{91}$ na qual se lê:

Bíos-Bíos, Apóllon- Apóllon, Hélios-Hélios, Kósmos-Kósmos, Fôs-Fôs.

Vida-Vida, Apolo-Apolo, Helio-Helio, Ordem-Ordem, Luz-Luz.

Em suma, a viagem de Parmênides tem haver com o Mundo Subterrâneo, mas também com a luz, um conceito que para os gregos não é alegórico, mas, em todo caso, metafórico. ${ }^{92}$ Mais que isso, se poderia dizer que ela apresentava imediatas conotações de conhecimento, verdade, e vida.

\subsubsection{0. "osámenai kráton ápo chersì kalýptras" ("depois de haverem descoberto a cabeça com as suas mãos") (B 1.10).}

0 gesto é ambíguo, porque pode ser um sinal de luto ou de confiança, ${ }^{93}$ e também pode explicar por que as Helíades, no reino da Noite, ocultavam sua luminosidade, ${ }^{94}$ mas em um contexto como este como não the atribuir uma conotação de desvelamento, de revelação do oculto, de manifestação da verdade? ${ }^{95}$

\subsubsection{1. "éntha pýlai Nyktós te kaì Ématós eisi keleúthon" ("ali estão as portas das sendas da Noite e do Dia") (B 1.11).}

Os caminhos da Noite e do Dia na Odisséia (10.86) se cruzam na entrada do mundo subterrâneo, e em Hesíodo (Th. 748-750) o palácio de ambos se localiza no Tártaro, hóthi Nýx te kaì Hemére âsson ioûsai

allélas proséeipon ameibómenai mégan oudòn

chálkeon.

onde Noite e Dia, se encontrando próximos,

trocam saudações, passando alternadamente pelo

grande umbral

de bronze.

Por outro lado, o começo do verso parmenídio éntha pýlai é característico das referências ao Tártaro. ${ }^{96}$ Se a geografia infernal parmenídia fosse a mesma que a homérica e hesiódica, este verso sugeriria que a viagem do koûros leva ao ádyton subterrâneo da Noite, mas como estamos vendo, os indícios do filósofo são um tanto contraditórios.

Além da localização que se queira dar à Noite e ao Dia, as portas abertas ou fechadas são também um símbolo de acesso permitido ou negado à verdade. No começo dos poemas atribuídos a Orfeu, apareciam um verso que conhecemos em duas versões:

a) aeíso xynetoîsi thýras $d^{\prime}$ epithesthe, bébeloi.

Cantarei para conhecedores; fechadas as portas, profanos.

b) fthégxomai hoîs thémis estí thýras $d^{\prime}$ epithesthe, bebeloi.

Falarei a quem é lícito; fechadas as portas, profanos.

As portas do conhecimento iniciático estão fechadas aos profanos, em troca se abrem para Parmênides, o permitindo acessar este tipo de conhecimento. 0s "conhecedores" (xynetoîsi) dos quais se fala na primeira versão são como "o homem que sabe" citado em B 1.3. E se na segunda versão se proclama que apenas the é lícito (thémis) contar estas coisas a determinadas pessoas, é significativo que thémis seja (B 1.28) um dos princípios que “acompanham" Parmênides.

\subsubsection{2. "autaì d' aithériai" ("estas, situadas no éter") (B 1.13).}

As portas estão no éter, na parte alta da organização cósmica tradicional, o que parece novamente 
situar o itinerário por um caminho celeste. ${ }^{98}$ Com efeito, a descrição recorda muito, neste caso, a que faz Homero do transito do carro de Hera através das portas do céu, guardadas pelas Horas. ${ }^{99}$

\subsubsection{3. "Díke polýpoinos" ("Justiça pródiga no pagar") (B 1.14).}

A personificação da Justiça (Díke) é muito antiga, como nos conta Hesíodo (0p. 251). É filha de Zeus, senta-se ao seu lado, e queixa-se quando é maltratada para que seu pai castigue o pecador. ${ }^{100} 0$ significativo é, no entanto, que o epíteto polýpoinos aparece, apenas, duas vezes na literatura grega, ${ }^{101}$ e em ambos os casos qualificando a Díke: aqui, e em um fragmento órfico: ${ }^{102}$

tôi dè Díke polýpoinos eféspeto pâsin arogós

[Ela] o seguiu de perto [sc. a Zeus], a Justiça pródiga em pagar, de todos protetora.

0 paralelo literal levou Kern e Rathmann ${ }^{103} \mathrm{a}$ sustentarem que Parmênides havia se inspirado em um poema órfico. Os comentadores de Parmênides se mostram relutantes em aceitar esta afirmação, ${ }^{104}$ contudo não é motivo suficiente para negá-la o argumento de Coxon, que se limita a assinalar que “a data do verso órfico é muito incerta". ${ }^{105}$

Com efeito, sobre a data do verso há um dado muito interessante. Lemos nas Leis de Platão, referindo-se a um "antigo relato" (palaiòs lógos) ${ }^{106}$ o seguinte:

ho mèn dè theós, hósper kaì ho palaiòs lógos, archén te kaì teleutèn kaì mésa tôn ónton hapánton échon, eutheíai peraínei katà fýsin peripoeuómenos• tôi dè aeì synépetai díke tôn apoleipoménon toû theíou nómou timorós.

0 deus que, como diz o antigo relato, tem o princípio, o fim e o centro de todos os seres, se encaminha na direção do seu fim seguindo as revoluções da natureza. Não deixa de segui-lo [sc. Zeus] Justiça, vingadora das infrações da lei divina.

E, para completar o círculo, um escólio à passagem platônica (317 Greene) nos adverte: palaiòn dè lógon légei tòn Orfikón, hós estin hoûtos -

Zeùs arché, Zeùs méssa, Diòs d' ek pánta tétyktai• Zeùs pýthmen gaíes te kaì ouranoû asteróentos.

0 "antigo relato" alude ao órfico, que é o seguinte:

Zeus princípio, Zeus centro, por Zeus tudo está perfeitamente construído;

Zeus fundamento da terra, e do céu estrelado.

Poderia se arguir que o autor do escólio cita versos posteriores a Platão (como fazem frequentemente os Neoplatônicos), mas a antiguidade destes versos é garantida pela sua presença no próprio Hino a Zeus de Orfeu que cita o Papiro de Derveni. ${ }^{107}$

Se Platão colocou em prosa, na primeira parte do texto que nos ocupa, uns versos órficos acerca de Zeus princípio, e fim, está claro que também colocou em prosa, na referência a Justiça, como indicou Burkert, $^{108}$ um fragmento órfico igual, ou muito similar ao que mencionei. Com efeito, parece que synépetai é a transcrição, no presente, e no ático da época, do verbo, próprio a épica, eféspeto. E o raríssimo adjetivo poético polýpoinos foi traduzido pelo filósofo por uma perífrase mais compreensível: "tôn apoleipoménon toû theíou nómou timorós" (vingadora das infrações da lei divina).

0 fato de que Platão aluda a um verso como este como procedente de "um antigo relato", que é a expressão típica do filósofo para referir-se aos textos órficos, e o fato de que apareça imediatamente atrás da citação de um fragmento que nos consta, por outras fontes (já desde o P. Derveni), ser órfico, nos faz ter por muito provável que a expressão apareça em um texto órfico considerado já antigo no século IV a.C., em razão do que tem que ser, pelo menos, do final do VI, ou do princípio do V a.C. ${ }^{109}$

Temos que adicionar o testemunho de um interessante fragmento cerâmico apúlio que esteve em Ruvo, e do qual apenas temos um desenho, ${ }^{110}$ que advoga pela relação de Dike com o mundo ultramundano, e com o orfismo.

Em um palácio com colunas se encontra Perséfone, e Hécate. Esta última recebe Orfeu que se encontra às portas do edifício. Na esquerda da composição se encontra Dike sentada, enquanto que uma Nike alada abre uma porta. Neste caso a men-
100. A ideia é desdobrada pelos tragediógrafos (por ex. S. $\mathrm{OC}$ 1381s. "eíper estin he palaifatos / Díke xýnedros Zenòs archaiois nómois", "se a Justiça celebrada desde a antiguidade continua sentada junto às normas de Zeus que regem desde sempre"), conhece um desenvolvimento filosófico em Anaximandro B 1 D.-K., em Heráclito frs. 45, 80, 52 Marcovich (= B 23; 28; 94 D.-K.), e acaba convertendo-se em um tópico, cf. por exemplo Philo de Iosepho 48, Plut. Alex. 52, Arrian. Anab. 4.9.7, Aelian. Fr. 25 (II 197.21 Hercher), Liban. Decl. 49.2.11. Cf. Cerri (1999, p. 104s) 101. Desconto as fontes que o empregam em citações, ou comentários, de uma ou outra passagem.

102. OF 233.

103. Kern (1920, p. 40, n. 2), Rathmann (1933, p. 64, e 80, n. 14); cf. também Lobeck (1839, p. 396); Schuster (1869, p. 27); Kern (1888, p. 52); Bowra (1953, p. 49); e Brisson (1987, p. 64; 1990, p. 2889).

104. Por exemplo, Tarán (1965, p. 15) conclui que disso não se deve inferir uma influência órfica (sem explicar, naturalmente, por que não; ademais, o autor parece haver decidido de antemão que não a havia); cf. West (1983, p. 109).

105. Ad loc., p. 163. 106. Cf. Bernabé (1998, pp. 47, 64s; 2011, pp. 190-191); Casadesús (1997, p. 65s). 107. OF 14. Cf., ademais Casadesús (2002). 108. Burkert (1969, p. 11, n. 25); cf. West (1983, p. 89s, n. 35). 109. Cf. mais materiais sobre Dike entre os órficos, e em Platão, em Jiménez San Cristóbal (2005); Bernabé (2011, pp. 189-204). 110. Antiga coleção Fenícia c. 350 a.C.; cf. Bernabé (2011, p. 203, com bibliografia). 
111. Marsoner (1976-1978, p. 128) 112. Mesmo que a necessidade de persuadir a Dike implique que o caminho não é habitual, senão excepcional, cf. Gómez Lobo (1999, p. 33), assim como o paralelo da persuasão de Hermes a Hades em hCer. 336-38, cit. em § 2.2.9. 113. A interpretação se apoia, ademais, em um testemunho de Hesíodo (Th. 748-750) sobre o palácio da Noite e o do Dia, aos quais já me referi (§ 2.2.11). 114. Conche (1996, pp. 50-53). 115. Que estranha a Coxon (1986, p. 164s).

116. Pi. Fr. 33,1 Maehler $=$ 65 Cannatà Fera (OF 443), P. Derveni col. 6.4-5, Pl. Cra. 400c (OF 430 I). Cf. Bowra (1953, p. 49); Santamaría (2005); Bernabé (2012, p. 16-18) 117. Gemelli Marciano (2008, p. 35) vê em eos oseie no verso 17 "a estrutura de uma fórmula mágica".

0 problema é que encontramos similares "fórmulas mágicas" em sequências tomadas ao acaso de autores pouco suspeitos de magia como "ptéseos hosei" em Philo spec. leg. 4.128; "ófeos, hoseí" em Psalm. 57.5; "póleos hoseí" em Iustin. dial. Triph. 34.5; etc. Sobre a persuasão cf. § 2.2.9, e n. 85 118. Passo por alto (porque não

tenho elementos novos para fornecer) a descrição detida da abertura das portas, sobre a qual cf. os interessantes comentários de Ranzato (2011, pp. 34-36), que põe em relevo as conexões entre a descrição do percurso do carro esta (com a função dos eixos ou o som chiante).

119. Pi. N. 6. 53-54 "kaì taûta mèn palaióteroi / hodòn amaxitón heûron" ("tudo isso configura o caminho real que meus predecessores encontraram"). Cf., ainda, Emp. 96.2-3 Wright (B 133.2-3 D.-K.) "hêiper te megíste / peithoûs anthrópoisin hamaxitòs eis fréna píptei" ("ali onde é mais largo o caminho real de persuasão

que desemboca na inteligência dos homens"). Não creio que seja uma coincidência que o caminho real se relacione com a persuasão. 120. Publicada por Jordan (1992) e republicada em $0 F 830 c$. 0 texto se encontra também com ligeiras variações em OF 830e 5-6, e parciais em $0 \mathrm{~F} \mathrm{830d} \mathrm{4,} \mathrm{f} \mathrm{4,} \mathrm{e} \mathrm{nos} \mathrm{chamados}$ "Hexámetros Getty" de Selinunt col. II 19-20 (JORDAN-KOTANSKY, 2011), bem como em novo exemplares por Rocca (2009). Cf. Bernabé (2003), e no prelo 2. 121. Leitura de D' Alessio (1993): K[OI]FRESILLYTO [vac.?] Jordan. 122. Cf. Rocca (2009, pp. 42-43). sagem é que Orfeu conseguiu da rainha infernal um melhor destino para os iniciados no Além (marcado pela Vitória que abre a porta), mas está claro que a Justiça preside e serve de garantia deste destino.

No proêmio parmenídeo, Díke aparece no centro da composição em anel, enfatizando sua importância no proêmio. ${ }^{111}$ Teríamos que considerar o porquê Parmênides a situa aqui, em uma porta que tem muito em comum com uma entrada ao outro mundo. 0 Além na concepção antiga se situa no Hades (de modo que as portas, ainda que aithériai, agora parecem ter a ver com a entrada ao Hades).

Mas, além disso, o Além é também o lugar no qual se unem o passado, o presente, e o futuro, 0 lugar no qual se conhecem todas as coisas (por isso Odisseu desce ao Hades, por isso Eneias desce aos infernos na Eneida para conhecer o futuro de Roma).

0 mais provável é que Parmênides desejou indicar, com a cenografia ultramundana unida a presença de Justiça, que, ao penetrar nestes terrenos, ascendeu a um tipo de conhecimento especial, mas que, além disso, o fez legitimamente, dentro da ordem devida das coisas. ${ }^{112}$ Não é pura imaginação, senão uma maneira de expressar a legitimidade do seu acesso a um certo tipo de conhecimento, baseada em uma tradição sul itálica seguramente bem conhecida por seus leitores/ouvintes.

\subsubsection{4. "kleîdas amoiboús" ("chaves alternativas") (B 1.14).}

0corre, geralmente, de se interpretar que 0 adjetivo tem aqui o sentido de "alternativas" (cf. amoibadón em B 1.19), ${ }^{113}$ enquanto que Conche, em uma larga explicação ilustrada com imagens, considera que 0 adjetivo quer dizer "que se adapta à fechadura". ${ }^{114} 0$ termo, no entanto, não parece trivial, e me parece que o filósofo desejou, uma vez mais, jogar com a ambiguidade, prolongada com 0 uso do plural kleîdas, ${ }^{115}$ que se explicaria muito bem se Justiça tivesse a capacidade de abrir portas que levam a lugares diferentes como compensação de antecedentes diferentes. Tudo isso é consistente com uma visão infernal. Com efeito, no Papiro de Bolonia, que contem uma catábase órfica, lemos (OF 717 123): es é]legchos [aeì ga]nóonti pr[osó]poi

pá]seisin eoik[óta] m[i]sthòn op[e]deîn

Dikaiosýn]es thygáte[r p]olýfemos Amoibé

... a prova sempre com rosto amável

para atribuir o pagamento adequado a cada um a filha da Justiça, a renomada Compensação.

A amoibé, "compensação" é um conceito órfico que também é designado por poiné, se repete em diversos textos. ${ }^{116} \mathrm{E}$ a compensação associa cada uma das almas a uma dupla possibilidade de enfrentamento, a do proêmio, ou a do castigo, e a que se vejam obrigadas, dentro do Hades, a tomar uma de duas direções.

As Helíades convencem, com suaves palavras, a Justiça para que abra a porta. ${ }^{117}$ A persuasão atua como um meio de convencimento uma vez mais. ${ }^{118}$

\subsubsection{5. "kat' amaxitón" ("pelo caminho real (das carroças)") (B 1.20).}

A expressão resulta estranha porque amaxitón é um caminho de carros, o que parece contradizer a imagem de um caminho não humano. 0 uso parmenídeo da expressão poderia explicar-se porque se insere deliberadamente em uma tradição. Com efeito, Píndaro utiliza hodòn amaxitón como uma metáfora do caminho poético encontrado pelos poetas anteriores, mas o que me parece mais interessante é que a expressão kat' amaxitón é utilizado nas epoidaí da Magna Grécia. É o caso de uma tábua de chumbo de Falasarna (IV a.C., Museu de Atenas), ${ }^{120}$ em cujas linhas M-N se lê:

ólbio[s] hôi k<a>tà dè s[k]edathêi kat' amaxitòn 'ió' $\mathrm{k}$ [aì] fresìn autò [s] ${ }^{121}$ échei makáron \{makaron\} kat' amaxitòn $\mathrm{a}[\mathrm{u}]$ dán.

Feliz aquele para quem se expandiu pelo caminho real 0 "ió"

e tem o mesmo no seu coração sobre o caminho real dos felizes a voz.

É muito significativa a reiteração da referência ao caminho real, e a sua relação com a 
divindade, ${ }^{122}$ e com o ambiente iniciático, que se manifesta tanto no grito místico "ió" como na iunctura ólbio[s] hôi, característica dos desejos de felicidade (makarismoi) que se dirigem aos iniciados que alcançam uma vida melhor no outro mundo.

\subsection{A acolhida da deusa.}

\subsection{1. "theà prófron hypedéxato, cheîra dè cheirí, / dexiterèn hélen" (B 22-23).}

A deusa acolhe benevolamente ao recém chegado, com um gesto de reconhecimento característico dos benevolentes: a dexíosis, que tem também interessantes conotações no mundo dos mistérios. ${ }^{123}$ Há, por outro lado, um detalhe digno de menção nesta cena, e desta vez não se trata de algo que Parmênides tenha dito, mas de algo que não disse. Depois de falar de um modo enormemente preciso sobre as características do caminho, do carro, e da forma como se apressava, das Helíades, e de como se desvelam, e, principalmente, das portas e seus ferrolhos, uma vez que o carro, depois de atravessar as portas, chega ao caminho real (amaxitón) Parmênides se encontra ex abrupto com a deusa, como se ela estivesse no meio do caminho. Nem uma palavra de sua morada, nem de como se chega a ela; nem uma menção do seu trono, do seu vestido, do seu vestido. Apenas a deusa, o gesto de acolhida, e sua palavra de sabedoria. Uma deusa, a diferença do que é habitual na tradição épica, sem epítetos que se refiram a características físicas, ou culturais, sem qualquer agregado, da mesma forma que nem Memória, nem Gaia, nem a Moira, nem, na maioria das vezes, Perséfone recebem epítetos nas lâminas. ${ }^{124}$ Uma vez mais, Parmênides segue os hábitos da poesia religiosa mistérica, na medida em que renuncia apresentar características, pistas, da deusa.

\subsection{2. "koûr" ("jovem") (B 1.24).}

Koûros não é uma indicação de idade, nem se trata de uma designação honorífica, ${ }^{125}$ senão que tem, aqui, um claro valor iniciático, como tornou manifesto Burkert. ${ }^{126}$ Além disso, o uso desse nome situa a Deusa em um papel bem conhecido de di- versas divindades, o de kourotrófos um epíteto que se aplica às deusas que têm sobre a sua tutela a transição dos jovens à idade adulta. É interessante que, embora tudo pareça indicar que o koûros é Parmênides, o autor espera que quem ouça, ou leia, o poema se identifique com o herói. ${ }^{127}$ A indicação "jovem acompanhante de cocheiras imortais" ("athanátoisi synáoros henióchoisin") confere ao koûros um status de familiaridade ao divino.

\subsection{3. "chaîr" ("salve") (B 1.26).}

Como destacou Sourvinou-Inwood, ${ }^{128}$ o uso de chaîre por parte de uma divindade para dirigir-se a um ser humano tem uma significação muito característica na escatologia grega, já que é relativamente habitual em contextos nos quais um morto alcança uma situação privilegiada, tais como a heroicização, ou a imortalidade. Encontramos uma saudação assim em uma lâmina de Turios (OF 487.3), enquanto que em outras, reciprocamente, o iniciado pode utilizar a mesma fórmula de saudação para dirigir-se aos deuses do Além, como Perséfone, ou Plutão (OF $495,495^{\mathrm{a}}$, e $\left.496 \mathrm{k}\right){ }^{129}$

\subsection{4. "epeì oúti se moîra kakè proúpempe néesthai / ténd' hodón" ("que não foi um mal fardo que te levou a tomar este caminho") (B 1.26).}

A deusa não nomeada tranquiliza Parmênides dizendo-lhe que não é um mal fardo o que o levou até ali. A crítica é unânime em entender que a advertência tem sentido se o normal for que um ser humano vai a este lugar quando tem um mal fardo, isto é, quando se morre. 0 cenário seria, portanto, o Além. E o Além mais habitual para os gregos é o Hades, o mundo subterrâneo.

\subsection{5. "thémis te dike te" ("norma e justiça") (B 1.28).}

thémis e díke são quase sinônimos em Esquilo. ${ }^{130}$ Não parece que aqui estejam personificadas. ${ }^{13}$ Sobre a presença de ambas entidades é pertinente
123. Cf. Herrero (2011b, p. 58 n. 64)

124. Apenas Urano, um deus masculino, recebe o tradicional epíteto asteróeis, e Perséfone é qualificada de hagné em duas lâminas de Turios (OF 489-490) 125. Jeanmaire (1939, pp. 26-43).

126. Burkert (1969, p. 14, e n. 32). Cf. mais detalhamentos em Cosgrove (1974, p. 94), Cordero (2005, p. 39), e Palmer (2009, p. 58), com bibliografia. Tarán (1965, p. 16) considera que marca as diferenças entre a natureza divina e a humana.

127. Como assinala

acertadamente, Mourelatos (1970, p. 16) que põe em relevo, além disso, que Parmênides evita apresentar-se como personagem, e dizer detalhes sobre si mesmo, à diferença de Hesíodo, Xenófanes, ou Empédocles. Chega demasiado longe Morgan (2000, p. 74)

quando afirma que "the koûros

... cannot be identified with

Parmenides as constructor of poem".

128. Cf. Sourvinou-Inwood (1995, p. 95s), onde se pode encontrar um bom número de exemplos deste uso.

129. Bernabé-Jiménez San Cristóbal (2008, pp. 96-97). 130. A. Eum. 414; a observação é de Coxon (1986, p. 168).

131. Cf. o estado da questão em Conche (1996, p. 60s). 
recordar que no proêmio dos poemas órficos ( $\S$ 2.2.11) o eu que vai pronunciar a revelação dos poemas apenas o faz a quem é thémis fazê-lo, e também que Díke é uma entidade relevante neste ambiente (§ 2.2.13).

\subsection{6. "Aletheíes" ("da Verdade") (B 1.29).}

A deusa enfatiza que o quê ela vai o transmitir, a Parmênides, é a verdade. A ênfase sobre a verdade de uma nova doutrina aparece reiteradamente na literatura órfica. Pode-se citar um par de exemplos importantes, e antigos. ${ }^{132}$

0 primeiro exemplo é de uma das chamadas "lâminas de ouro", a de Farsalo (c.a. 350-300 a.C.) na qual são dadas instruções à alma para a sua viagem ao Além. A voz que instrui o iniciado o adverte que estarão na passagem da alma alguns guardiões da fonte de Mnemósyne (a Memória), e o que deve fazer: ${ }^{133}$

toîs dè sý eû mala pâsan aletheíen kataléxai.

E tu dirás a eles absolutamente toda a verdade.

0 curioso é que a tal verdade (indicada no verso seguinte) não é outra coisa senão a contrassenha que identifica o morto como um iniciado: "Sou filho da Terra e do Céu estrelado". Etimologicamente "alétheia" ("verdade") é um composto privativo de "léthe" ("esquecimento"), o que quer dizer que "verdade" se concebe como o "não esquecimento" ${ }^{134}$ No universo das lâminas, a verdade não é outra coisa senão aquilo que não se deve esquecer, o que foi aprendido na iniciação. Quando se pede ao iniciado que diga exatamente

132. Cf. Scalera Mc Clintock (1990); Tortorelli Ghidini

(1990).

133. OF 477.7 .

134. Cf. Pugliese Carratelli (1988,

p. 165); Bernabé-Jiménez San

Cristóbal (2008, pp. 37-39)

135. Scalera Mc Clintock (1990);

Bernabé (2008)

16. Cf. n. 60

137. Cf. Namia (1977, p. 289);

Feyerabend (1984)

138. Couloubaritsis (1986, p.

39. Pace Bowfa (1 toda a verdade aos guardiões da lagoa de Mnemósyne para que estes lhe permitam beber, o que se the pede é que recorde a verdade revelada, a contrassenha indicativa da pertença a um grupo sabedor de certas doutrinas cuja verdade última apenas os iniciados conhecem.

Nas lâminas de osso de Olbia se lê alétheia depois da expressão bíos / thánatos / bíos, o que parece aludir a que uma vida depois da morte é a "verdade" proclamada como algo que não deve ser esquecido. $^{135}$
Não é necessário pensar que a deusa é Mnemósyne ${ }^{136}$ para advertir quanto às semelhanças do prólogo parmenídeo com o esquema iniciático dos órficos. ${ }^{137}$

\section{Conclusões.}

\subsection{Razões do proêmio.}

A partir da classificação dos tipos de explicações do proêmio traçada por Couloubaritsis ${ }^{138}$ (literais, religiosas, alegóricas, e racionalistas), segue que não creio que o poema descreva uma experiência real, nem que seja uma alegoria. ${ }^{139} 0$ primeiro se nega por si mesmo; ninguém pode crer hoje que o filósofo viajara ao outro mundo; me detenho a falar de experiências xamânicas no mundo grego antigo, e considero que um sonho, como pretende Conche, é muito pouco provável. 0 proêmio de Parmênides é muito organizado, muito coerente e elaborado para ser interpretado como uma experiência onírica.

A possibilidade de que se trate de uma alegoria deve também ser excluída. Parmênides não descreve uma cena que deva ser interpretada em outros termos, de maneira que cada elemento signifique outra coisa (à maneira em que Sexto Empírico interpreta a passagem). Os elementos mais característicos que se apresentam são o que se diz que são, embora evoquem todo um jogo de conotações específicas que os contemporâneos de Parmênides percebiam imediatamente. Consequentemente, o proêmio é, em todo caso, conotativo, mas não alegórico.

Tentaria definir o proêmio como a elaboração literária do acesso a uma grande verdade que o autor interpreta como uma revelação religiosa: da impressão de que Parmênides considera que o discurso sobre o ser não é apenas mais uma verdade, é a Verdade; em consequência, situou o que tinha para dizer no âmbito no qual, em sua época, se situavam as verdades profundas, as explicações últimas da realidade. Parmênides não acreditou, provavelmente, sequer em si mesmo, que aquela ideia básica, e genial de que "o que é, é" havia sido produto da sua própria reflexão, e, desde as coordenadas ideológicas da religião de sua época, e de seu entorno, teve 
que interpretar que ocorreu porque alguém (uma divindade cuja identidade ele não sabia) o inspirou. Teve que considerar impossível que tivesse sido uma mera ocorrência de um ser humano como ele, como o simples emprego de sua razão, bem entendido que tampouco considerou que tivesse sido possível sem a intervenção da razão em absoluto, de modo que deveria ser algo que estava mais além, que se situava no âmbito das verdades eternas. Tal âmbito não é outro senão o da onisciência da divindade. E, por outro lado, nos Mistérios, o espaço em que a verdade divina se transmite aos seres humanos é o espaço iniciático, entre o nosso mundo, e o Além, entre o humano e o divino, entre a vida e a morte. Consequentemente, esse é o cenário no qual Parmênides situa a revelação, que pretende, ademais, apresentar como legítima, e não como uma intromissão indevida de um mortal nas verdades dos deuses.

Como temos observado, um bom número de fatos sugerem um conhecimento por parte de Parmênides da tradição órfica, e da mistérica, especialmente da sul itálica. E, com efeito, para descrever a transmissão da verdade profunda ele utiliza a linguagem dos Mistérios, que é em si ambígua, pregnante, e evocativa.

\subsection{A deusa.}

No mundo sul itálico da época de Parmênides, as divindades relacionadas com o iniciático são femininas (Noite, Mnemósyne, Perséfone), de modo que o interlocutor do filósofo será uma deusa, como todas as demais divindades que intervêm no cenário. Penso que os esforços de identificar a deusa estão condenados ao fracasso. Se o poeta não disse o seu nome é por que não quer dizê-lo, senão que prefere deixar na ambiguidade sua personalidade, sem a identificar com nenhuma deusa conhecida. É uma deusa não nomeada, que evoca a outras da tradição, como as que acabo de citar, porque está construída com características de todas elas. Por isso, os críticos que assinalam que a deusa de Parmênides apresenta características de uma, ou de outra, destas divindades têm razão todos eles, porque Parmênides as tomou de cada uma delas para caracterizar a sua deusa, mas, dado que não a identifica por seu nome, ela é todas e nenhuma. Não devemos descartar, por outro lado, que o filósofo pode estar convencido de que uma deusa o havia inspirado, sem alcançar a determinação de qual delas, e que isso pode ter condicionado sua ambiguidade ao nos apresentá-la.

A deusa da mesma forma nunca chama por seu nome a Parmênides, de tal forma que no resto do poema, quando a deusa o faz as revelações, o ouvinte/leitor sente como se as revelações estivessem sendo feitas a si próprio.

\subsection{A viagem e o cenário da revelação.}

Parmênides expressa o acesso ao conhecimento como um caminho, porque essa era a maneira como se concebia a aquisição do conhecimento na época. A lírica havia se familiarizado com a identificação do carro das Musas com o veículo da inspiração, de modo que o modelo já era consistente. A iniciação também se concebia como um caminho, tal como o acesso ao Além. De todas estas tradições derivou Parmênides seu poderoso imaginário. Mas, tal como ocorre com a deusa, as discussões sobre se a viagem têm lugar por um percurso infernal, ou celeste, são igualmente estéreis. 0 cenário que apresenta não é deste mundo, e o filósofo se nutre de viagens ultramundanas diversas que encontra na tradição, mas não quer identificá-la com nenhuma em concreto. ${ }^{140}$ Ainda diria mais: ele define o espaço com características tradicionais que pertencem, umas às sendas do céu, e outras, sem dúvida as mais numerosas, às sendas que levam ao Além, e ao inframundo, de modo que não são coerentes entre si, e tal coisa não pode senão ser deliberada. Assim mesmo, incorpora expressões como kat' amaxitón que, à luz das epoidaí sul itálicas, parece estar relacionada com um ambiente místico. Dá a impressão de que Parmênides deseja criar um espaço iniciático fora deste mundo, distante das limitações marcadas pelo conhecimento, mas que tampouco quer identificá-lo seja com o céu, seja com o subterrâneo; é o espaço não terreno, não humano, não habitual. A realidade expressada pelo filósofo é assim muito mais rica, porque a ambiguidade, frequentemente, é mais sugestiva, e polivalente que a concreção. ${ }^{141}$
140. Nas palavras de Cosgrove (2011, pp. 38-39): "neither anábasis nor katábasis, the journey to the realm of the goddess is better viewed as a unique apóbasis" (na n. 65 assinala que $o$ termo foi sugerido por Mourelatos). 141. Cf. Miller (2005, p. 18ss) 


\subsection{0 proêmio, tampouco, é uma mera estratégia literária.}

Todavia, não quero ser mal entendido nisto, Parmênides não utiliza o imaginário tradicional como uma opção dentre diversas outras possibilidades de apresentar sua mensagem, como uma estratégia deliberada, que prefere esta forma em lugar de uma eventual apresentação de sua teoria filosófica como poderia ser a dos milésios. 0 mais certo é que, em sua cultura oral e arcaica, exista a convicção de que a verdade é inspirada. Seu antecessor poético, Homero, invocava a musa ao começo dos poemas não como recurso literário, senão porque acreditava que era ela a depositária da tradição, dos mitos, nomes e temas que seriam os ossos e a carne dos seus versos. Hesíodo apresentava as próprias musas como inspiradoras da sua poesia que, de modo semelhante à deusa parmenídea, o faz saber que elas conhecem tanto do verdadeiro, como do falso.

Parmênides considera que a verdade a qual chegou é revelada, que the foi transmitida pela deusa, e no espaço próprio de tais revelações, o iniciático, embora considere que sua própria atitude, seu próprio desejo e predisposição possam ter facilitado sua condução à senda adequada, e provavelmente por isso inicie o poema antes do encontro com a deusa. Não é uma pura revelação, senão transmissão de conhecimento sobre os quais o filósofo deve raciocinar.

Ancorado na convicção de que a verdade que the chegou acerca do que é tem que ter sido revelada, ele reelabora a tradição para configurar seu próprio cenário. Nesta reelaboração, as contribuições literárias e ideológicas do orfismo são, ao menos, tão significativas como as de Homero, ou Hesíodo. Parmênides cria, assim, um cenário rico em significação, não filosófico desde uma perspectiva moderna, mas sem dúvida de enorme capacidade de evocação poética, para situar esse conhecimento sobre-humano onde ele deveria estar no seu tempo, e nas suas coordenadas: fora do mundo. Como faria, depois, Platão em suas descrições do Além, Parmênides põe o imaginário tradicional ao serviço de seus próprios interesses ideológicos, e literários, criando um cenário que tem o aroma, e o som, da tradição, mas que é, profundamente, original tal como a mensagem que nele se transmite.

Tradução de Thiago Rodrigo de Oliveira Costa

\section{Bibliografia}

ALVAR EZQuerRA, A. GONZÁlez CASTRO, J. F. (eds.), (2005). Actas del XI Congreso Español de Estudios Clásicos, I, Madrid.

BERNABÉ, A. (1996). “La fórmula órfica 'cerrad las puertas, profanos'. Del profano religioso al profano en la matéria", 'Ilu. Revista de ciencias de las religiones 1, p. 13-37.

(1998). “Platone e l'orfismo" en G. Sfameni Gasparro (ed.), Destino e salvezza: tra culti pagani e gnosi cristiana. Itinerari storico-religiosi sulle orme di Ugo Bianchi, Cosenza, p. 33-93.

(2002). "La théogonie orphique du Papyrus de Derveni", Kernos 15, p. 91-129.

(2003). “Las Ephesia Grammata. Génesis de una fórmula mágica", MHNH 3, p. 5-28.

(2004). Textos órficos y filosofía presocrática. Materiales para una comparación. Madrid.

(2004-2005-2007). Poetae Epici Graeci. Testimonia et Fragmenta. Pars II: Orphicorum et Orphicis similium testimonia et fragmenta, Fasciculi 1 et 2, Monachii et Lipsiae; fasc. 3, Berolini et Novi Eboraci.

(2007). “The Derveni Theogony: Many Questions and Some Answers", HSCPh 103, p. 99-133.

(2008). "Las láminas de Olbia", en Bernabé-Casadesús (eds.), p. 537-547.

(2011). Platão e o orfismo, Diálogos entre religião e filosofia, São Paulo.

(2012). "A brave netherworld: the Orphic Hades as utopia", en A. Mastrocinque y C. Giuffrè Scibona (eds.), Demeter, Isis, Vesta, and Cybele: Studies in Greek and Roman Religion in Honour of Giulia Sfameni Gasparro, p. 11-24.

En prensa 1. "Spatial Ambiguity in Plutarch fr. 178 Sandbach and the Derveni Papyrus".

En prensa 2. "The Ephesia Grammata. Genesis of a magical formula" en C.A. Faraone -D. Obbink (eds.), The Getty Hexameters: Poetry, Magic, and Mystery in Ancient Selinous, 0xford.

BERnABÉ, A.-Casadesús, F. (eds.), (2008). Orfeo y la tradición órfica: un reencuentro, Madrid.

Bernabé, A.-Casadesús, F.-Santamaría, M. A., eds. [2010]: Orfeo y el orfismo: nuevas perspectivas. http:// www.cervantesvirtual.com/obra/orfeo-y-el-orfismonuevasperspectivas--0/

BERnABÉ. A.-Jiménez San Cristóbal, A. I. (2008). Instructions for the Netherworld. The Orphic Gold Tablets, Leiden-Boston. 
BOWRA, C. W. (1953). Problems in Greek Poetry, Oxford.

BRISSON, L. (1987). “Proclus et l'orphisme”, en J. Pépin-H. D. Saffrey (eds.): Proclus lecteur et interprète des anciens, Aldershot, p. 43-104.

(1990). “Orphée et l’Orphisme à l'époque impériale. Témoignages et interprétations philosophiques, de Plutarque à Jamblique", ANRW II 36.4, Berlin-New York, 28672931.

BURKERT, W. (1969). “Das Proömium des Parmenides und die Katabasis des Pythagoras", Phronesis 14, 1-30 (= Kleine Schriften VIII: Philosophica, hrsg. von Th. A. Szlezák und K.-H. Stanzel, Göttingen 2008, 1-27).

(1999). Da Omero ai magi, Venezia.

(2007). Religión griega arcaica y clásica, trad. esp. de H. Bernabé, Madrid.

CASADESÚS, F. (1997). “Orfeo y orfismo en Platón”, Taula 27-28, 61-73.

(2002). “Influencias órficas en la concepción platónica de la divinidad (Leyes 715e 7717a 4)", Taula 35-36, 11-18.

CERRI, G. (1999). Parmenide di Elea: Poema sulla natura, Milano.

CONCHE, M. (1996). Parménide: Le Poème: Fragments, Paris.

CORDERO, N. L. (2005). Siendo, se es. La tesis de Parménides, Buenos Aires 2005 (trad. inglesa, By being, it is: the thesis of Parmenides, Las Vegas 2004).

CORNFORD, F. (1939). Plato and Parmenides, London.

COSGROVE, M. R. (1974). "The koûros motif in Parmenides", Phronesis 19, 81-94.

(2011). “The Unknown 'Knowing Man': Parmenides, B1.3”, CQ 61, 28-47.

COULOUBARITSIS, L. (1986). Mythe et philosoiphie chez Parménide, Bruxelles.

COXON, A. H. (1986). The Fragments of Parmenides, Assen/ Maasstricht,-Wolfeboro 1986 (rev. and exp. edition, Las Vegas - Zürich -Athens 2009).

CURD, P. (1998). The legacy of Parmenides: eleatic monism and later presocratic thought, Princeton [Las Vegas 22004].

D'ALESSIO, G. B. (1993). “Nota alla tavoletta plumbea di Phalasarna", ZPE 97, 290.

DEICHGRÄBER, K. (1958). Parmenides' Auffahrt zur Göttin des Rechts, Wiesbaden.

DIELS, H. (1897). Parmenides Lehrgedicht, Berlin.

DODDS, E. R. (1951). The Greeks and the Irrational, Berkeley-Los Angeles (trad. esp., Los griegos y lo irracional, Madrid 1960).

DÖRFLER, J. (1911). Die Eleaten und die Orphiker, Freistadt.

EDMONDS, R. III (ed.) (2011). The 'Orphic' Gold Tablets and Greek Religion. Further Along the Path, Cambridge.

FERRARI, F. (2003). “Il ritorno del kouros: tradizione epica e articolazione narrativa in Parmenide 28 B 1 D.-K.", en D. Accorinti -P. Chuvin (eds.), Mélanges F. Vian, Alessandria, p. $189-205$.

FEYERABEND， B. (1984). "Zur Wegmetaphorik beim Goldblättchen aus Hipponion und dem Proömium des Parmenides", RhM 127, p. 1-22.

FRÄNKEL, H. (1930). "Parmenidesstudien”, NGWG, p. 153-192.

(1968). Wege und Formen frühgriechischen Denkens: Literarische und philosophiegeschichtliche Studien, München.

GEMELLI MARCIANO, L. (2008). “Images and Experience: At the Roots of Parmenides' Aletheia", Ancient Philosophy 28, p. 21-48.

GÓMEZ-LOBO, A. (1981). “Retractación sobre el Proemio de Parménides", Revista Latinoamericana de Filosofía, 7, p. $253-260$.

(1999). El poema de Parménides: texto griego, traducción y comentario, Santiago de Chile (22006).

GOMPERZ, H. (1924). "Psychologische Beobachtungen an griechischen Philosophen", Imago 10, p. 2-34.

GRAF, F.-Johnston, S. I. (2007). Ritual Texts for the Afterlife. Orpheus and the Bacchic gold tablets, LondonNew York.

GUTHRIE, W. K. C. (1965). A History of Greek Philosophy, II, Cambridge.

HERRERO DE JÁUREGUI, M. (2011a). “Dialogues of Immortality from the Iliad to the Gold Leaves", en R. G. Edmonds III (ed.), 2011, p. 265-284.

(2011b). “Priam's Catabasis: Traces of the Epic Journey to Hades in Iliad 24", TAPhA 141, 37-68.

HÖLSCHER, U. (1969). Parmenides. Von Wesen des Seienden, Frankfurt a. M.

JAEGER, W. (1953). Die Theologie der frühen griechischen Denker, Stuttgart (trad. esp. México 1977).

JEANMAIRE, H.( 1939). Couroi et Couretes, Lille.

JIMÉNEZ SAN CRISTÓBAL, A. I. (2005). “El concepto de díke en el orfismo", en A. Alvar Ezquerra-J. F. González Castro (eds.), p. 351-361.

JORDAN, D. R. (1992). “The inscribed lead tablet from Phalasarna", ZPE 94, p.191-194.

JORDAN, D. R. -Kotansky, R. D. (2011). “Ritual Hexameters in the Getty Museum", ZPE 178, p. 54-62.

KERN, 0. (1888). De Orphei Epimenidis Pherecydis Theogoniis quaestiones criticae, Berolini.

(1890). "Zu Parmenides", AGPh 3, p. 173-176.

(1920). Orpheus. Eine religionsgeschichtliche Untersuchung, Berlin, 40 n. 2.

KINGSLEY, P. (1999). In the Dark Places of Wisdom, Inverness, Calif.

Kranz, W. (1916). “Über Aufbau und Bedeutung des parmenideischen Gedichtes", SPAW 1158-1176 (recogido en Studien zur Antiken Literatur und ihren Fortwirken, 
Heidelbeg 1967, 128ss.).

LESHER, J. H. (2008). "The Humanizing of Knowledge in Presocratic Thought", en P. Curd -D. W. Graham, The Oxford Handbook of Presocratic Philosophy, Oxford, p. 458-484.

LEVET, J. (1976). Le vrai et le faux dans la pensée grecque archaïque, Paris.

LINFORTH, I. M. (1941). The Arts of Orpheus, Berkeley-Los Angeles (reimp. New York 1973).

LOBECK, A. C. (1839). Aglaophamus, Regimontii.

MACÍAS, S. (2008). "Orfeo y el orfismo en la tragedia griega», en Bernabé-Casadesús (eds.), 1185-1215.

MANSFELD, J. (1964). Die Offenharung des Parmenides und die menschliche Welt, Assen.

MARSONER, A. (1976-1978). "La struttura del Proemio di Parmenide", AIIS 5, 127-181.

MARTÍN HERNÁNDEZ, R. (2005). “La muerte como experiencia mistérica. Estudio sobre la posibilidad de una experiencia de muerte ficticia en las iniciaciones griegas", 'Ilu 10, 85-105.

MARTINELLI, F. (1987) "Fra Omero e Pindaro: Parmenide poeta", en A. Capizzi-G. Casertano (eds.), Forme del sapere nei Presocratici, Roma, 169-186.

MEGIN0, C. (2002). El pensamiento de Homero sobre la realidad psicológica en la «Ilíada»: seis conceptos fundamentales, thymós, frén, nóos, êtor, kér y kradíe. Madrid.

MILLER, M. (2005). “Ambiguity and Transport: Reflections on the Proem to Parmenides' Proem", Oxford Studies in Ancient Philosophy 29, p. 1-48.

MORRISON, J. S. (1955). "Parmenides and Er", JHS, 75, p. 59-68.

MOURELATOS, A. P. D. (1970). The route of Parmenides, New Haven-London (Las Vegas-Zürich-Athens 22008.

NAMIA, G. (1977). "Sul chthónios basileús e la hierà hodós della laminetta orfica di Hipponion", Vichiana 6, p. 288-289.

PALMER, J. (2009). Parmenides and Presocratic Philosophy, Oxford.

PÉREZ DE TUDELA, J. (2007). introducción, notas y comentarios en Parménides, Poema (fragmentos y tradición textual), edición y traducción de Alberto Bernabé; epílogo de Néstor-Luis Cordero, Madrid.

PUGLIESE CARRATELLI, G. (1988). “La theá di Parmenide", PP. 43, p. 336-346.

(1990). Tra Cadmo e Orfeo. Contributi alla storia civile e religiosa dei Greci d'0ccidente, Bologna.

(1993). Le lamine d'oro 'orfiche', Milano.

RANZATO, S. (2011-20120). Il kouros alla ricerca della verità. Polivalenza delle immagini nel poema di Parmenide, Tesi di Dottorato, Università degli Studi di Pisa.

RATHMANN, G. (1993). Quaestiones Pythagoreae Orphicae Empedocleae, diss. Halis Saxonum.

ROCCA, G. (2009). Nuove iscrizioni da Selinunte, Alessandria.

SANTAMARÍA ÁlVAREZ, M. A. (2005). "Poinàs tínein. Culpa y expiación em el orfismo", en A. Alvar Ezquerra -J. F.González Castro (eds.), p. 397-405.

SASSI, M. M. (1988). "Parmenide al bivio", PP 43, 383-396.

SCALERA MCCLINTOCK, G. (1990). "Aletheia nelle tavolette di Olbia Pontica", Filosofia e Teologia 4, p. 78-83.

SCHUSTER, P. R. (1869). De veteris orphicae theogoniae indole atque origine, Diss. Lipsiae.

SOURVINOU-INWOOD, Ch. (1995). 'Reading' Greek Death to the End of the Classical Period, 0xford.

SUÁREZ DE LA TORRE, E. (2010). “La diosa lleva al iniciado por la vía del Ser: conjetura a Parménides B 13 D.-K.", en F. Cortés Gabaudan -J. V. Méndez Dosuna (eds.), Dic mihi musa, uirus. Homenaje al profesor Antonio López Eire, Salamanca, p. 659-662.

TARÁN, L. (1965). Parmenides. A Text with Translation, Commentary, and Critical Essays by--, Princeton.

TORTORELLI GHIDINI, M. (1990). "Aletheia nel pensiero orfico, 1. "Dire la veritá": sul v. 7 della laminetta di Farsalo", Filosofia e Teologia 4, p. 73-77.

(2006). Figli della terra e del cielo stellato. Testi orfici con traduzione e commento, Napoli.

TZIFOPOULOS, Y. Z. (2010). Paradise earned: the BacchicOrphic gold lamellae of Crete, Washington.

UNTERSTEINER, M. (1956). “La odós di Parmenide come via all'eón", StUrb, p. 22-69.

(1958). Parmenide. Testimonianze e frammenti, Firenze.

WEST, M. L. (1983) The Orphic Poems, Oxford.

YALOURIS, N. (1990). “Helios” LIMC V 1, 1005-1034.

Recebido em outubro de 2012 , aprovado em dezembro de 2012. 